\title{
Assessment of the Optimum Linker Tethering Site of Alternariol Haptens for Antibody Generation and Immunoassay Development
}

\author{
Luis G. Addante-Moya ${ }^{1}$, Antonio Abad-Somovilla ${ }^{1}$ (), Antonio Abad-Fuentes ${ }^{2}{ }^{\mathbb{C}}$, Consuelo Agulló ${ }^{1}$ \\ and Josep V. Mercader $2, *$ (D) \\ 1 Department of Organic Chemistry, University of Valencia, Doctor Moliner 50, \\ 46100 Burjassot, Valencia, Spain; luis.addante@uv.es (L.G.A.-M.); antonio.abad@uv.es (A.A.-S.); \\ consuelo.agullo@uv.es (C.A.) \\ 2 Spanish Council for Scientific Research, Institute of Agrochemistry and Food Technology, Agustí Escardino 7, \\ 46980 Paterna, Valencia, Spain; aabad@iata.csic.es \\ * Correspondence: jvmercader@iata.csic.es
}

Citation: Addante-Moya, L.G.; Abad-Somovilla, A.; Abad-Fuentes, A.; Agulló, C.; Mercader, J.V.

Assessment of the Optimum Linker Tethering Site of Alternariol Haptens for Antibody Generation and Immunoassay Development. Toxins 2021, 13, 883. https://doi.org/ $10.3390 /$ toxins 13120883

Received: 9 November 2021 Accepted: 6 December 2021 Published: 10 December 2021 Corrected: 16 February 2023

Publisher's Note: MDPI stays neutral with regard to jurisdictional claims in published maps and institutional affiliations.

Copyright: (c) 2021 by the authors. Licensee MDPI, Basel, Switzerland. This article is an open access article distributed under the terms and conditions of the Creative Commons Attribution (CC BY) license (https:/ / creativecommons.org/licenses/by/ $4.0 /)$.

\begin{abstract}
Immunochemical methods for mycotoxin analysis require antigens with well-defined structures and antibodies with outstanding binding properties. Immunoreagents for the mycotoxins alternariol and/or alternariol monomethyl ether have typically been obtained with chemically uncharacterized haptens, and antigen conjugates have most likely been prepared with mixtures of functionalized molecules. For the first time, total synthesis was performed, in the present study, to obtain two haptens with opposite linker attachment locations. The functionalized synthetic haptens were purified and deeply characterized by different spectrometric methods, allowing the preparation of bioconjugates with unequivocal structures. Direct and indirect competitive enzyme-linked immunosorbent assays, using homologous and heterologous conjugates, were employed to extensively evaluate the generated immunoreagents. Antibodies with high affinity were raised from conjugates of both haptens, and a structure-activity relationship between the synthetic haptens and the specificity of the generated antibodies could be established. These results pave the way for the development of novel highly sensitive immunoassays selective of one or two of these Alternaria mycotoxins.
\end{abstract}

Keywords: alternariol; antibody; ELISA; hapten design; immunoassay; linker site

Key Contribution: Two pure regioisomeric alternariol haptens were prepared. Alternariol immunoreagents were generated and characterized.

\section{Introduction}

Alternaria sp. fungi, particularly A. alternata, are ubiquitous plant pathogens and saprophytes that infect economically relevant crops such as cereals, vegetables, oilseeds, and fruits. Moreover, these microorganisms can contaminate these commodities after harvest even under refrigeration conditions. They are known to produce a wide variety of toxic secondary metabolites [1], and some of them have been identified by the EFSA Panel on Contaminants in the Food Chain (CONTAM) as a potential risk to human and animal health due to their toxicity and occurrence in food and feed. Surprisingly, there are no specific international regulations for any of the Alternaria mycotoxins, and the available data on toxicity, occurrence, and dietary exposure are still limited. In 2011, EFSA carried out the first assessment of the risk of these mycotoxins to human and animal health, based on government and published data [2]. More recently, EFSA conducted a survey on the dietary exposure of European consumers to Alternaria toxins [3]. This study found that $8 \%$ of these mycotoxins are present in food, with infants and other children being the most exposed population group, and fruit and fruit-based products contributing most to dietary 
exposure. It is therefore expected that the European Commission will soon set maximum levels for the most common Alternaria mycotoxins in foodstuffs.

Alternariol (AOH) and alternariol monomethyl ether (AME), two of the most important compounds belonging to the group of Alternaria mycotoxins, appear to be responsible for the teratogenic effects observed in animals. They have also been shown to inhibit in vitro the catalytic topoisomerase activity, which may be associated with human colon and oesophageal cancer [4]. Frequently, these two mycotoxins are found together in samples because they share most of the biosynthetic pathway [5]. AOH and AME have been detected in a wide variety of products, including lentils, carrots, tomatoes, berries, apples, pears, beer, wines, juices, and various grains and flours [6]. To evaluate the relative hazard level of these toxins to human health, a threshold of toxicological concern (TTC) for AOH and AME in adults of $2.5 \mathrm{ng} / \mathrm{kg}$ body weight per day was established as a reference parameter by the CONTAM Panel [2]. With limited data available, a 2016 German survey concluded that the percentage of TTC reached by the average adult daily exposure was $1400 \%$ and $280 \%$ for $\mathrm{AOH}$ and AME, respectively [7].

A variety of analytical techniques have been developed for monitoring Alternaria toxins in food, including liquid and gas chromatographic methods coupled to several detection systems, as well as different types of immunochemical assays [8,9]. Molecular affinity techniques nowadays represent alternative strategies for rapid, economical, and/or on-site monitoring of mycotoxins. The first antibodies and immunoassays for AOH were reported in 2011 [10,11]. Since then, a few immunoassays have been described using either polyclonal or monoclonal antibodies specific to $\mathrm{AOH}[12,13]$, and only one study has been published using an antibody specific to AME [14]. Additionally, Wang et al. have reported a generic antibody for both mycotoxins [15]. In all these studies, the immunogens used to generate antibodies against $\mathrm{AOH}$ were made by attaching the mycotoxin to the carrier protein, either directly by a Mannich-type reaction or by carbodiimide-mediated chemistry after nonselective carboxymethylation of the hydroxyl groups. Neither of these methods can be used to guide the position of attachment of the $\mathrm{AOH}$ molecular scaffold to the carrier proteins, so the antibodies were actually generated from an undefined mixture of functionalized haptens. More recently, Yao et al. published an immunoassay for $\mathrm{AOH}$ using a carboxymethyl hapten to generate polyclonal antibodies [16]. Disappointingly, no synthetic details and spectrometric data of the prepared hapten were provided in that work.

$\mathrm{AOH}$ and $\mathrm{AME}$ are the two most representative mycotoxins with a tricyclic benzochromenone chemical backbone. Moreover, these compounds contain hydroxyl, methyl, and other substituents in their chemical structure. It is well known that the orientation of the molecule, i.e., the way the hapten is displayed to the immune system, strongly influences the specificity of the generated antibodies. Thus, the synthesis of haptens with the optimal linker tethering site is critical, although it is hard to predict and challenging to perform. Surprisingly, deeply characterized haptens for AOH or AME with unambiguous chemical structures have not been published so far. The aim of the present study was to prepare, purify, and characterize two rationally-designed synthetic haptens of these Alternaria mycotoxins with a functionalized linker located at precise sites of the molecule. The ability of these novel immunoreagents to elicit a potent immune response, ultimately leading to high-affinity antibodies, was investigated. In addition, these bioconjugates also allowed the study of the relationship between the functionalization position in the hapten and the specificity of the resulting antibodies.

\section{Results and Discussion}

\subsection{Hapten Design and Synthesis}

The generation of antibodies to $\mathrm{AOH}$ has so far been based on the preparation of the required immunogens from $\mathrm{AOH}$ itself, which does not allow fine control over the specific position of the mycotoxin framework where the functionalized linker is introduced. In this study, we have synthesized two regioisomeric haptens of $\mathrm{AOH}$ from scratch. One of them, hapten AL $a$, incorporates a five-atom carboxylated aliphatic spacer arm through 
the hydroxyl group at C-9, whereas the other one, hapten $\mathbf{A L} \boldsymbol{b}$, incorporates the same linker via the hydroxyl group at C-3 (Figure 1). In contrast to previous strategies, these two haptens allowed the preparation of bioconjugates with well-defined compositions.<smiles>[R2]Oc1cc(C)c2c(c1)oc(=O)c1c(O)cc(O[R2])cc12</smiles>

Alternariol: $\mathrm{R}^{1}=\mathrm{H} ; \mathrm{R}^{2}=\mathrm{H}$

Alternariol monomethyl ether: $\mathrm{R}^{1}=\mathrm{CH}_{3} ; \mathrm{R}^{2}=\mathrm{H}$

Hapten ALa: $\mathrm{R}^{1}=\left(\mathrm{CH}_{2}\right)_{4} \mathrm{CO}_{2} \mathrm{H} ; \mathrm{R}^{2}=\mathrm{H}$

Hapten ALb: $\mathrm{R}^{1}=\mathrm{H} ; \mathrm{R}^{2}=\left(\mathrm{CH}_{2}\right)_{4} \mathrm{CO}_{2} \mathrm{H}$

Figure 1. Chemical structures of alternariol, alternariol monomethyl ether, and the synthetic haptens.

The synthetic strategy for preparing hapten AL $\boldsymbol{a}$ was based on a convergent methodology previously used by several research groups to synthesize $\mathrm{AOH}$ and other structurally related molecules [17-20]. A key step in this synthesis is a $\mathrm{Pd}(0)$-catalyzed cross-coupling reaction between an aryl triflate (4), which already contained the spacer arm, and an appropriately functionalized arylboronic acid (6) (Scheme 1). The aryl triflate 4 was prepared in two steps from the readily available 1,3-benzodioxinone 1 [21,22]. First, an O-alkylation reaction with methyl 5-bromovalerate was performed under standard Williamson ether synthesis conditions. The alkylation process produced a 6:1 mixture of di- and monoO-alkylation products, 2 and $\mathbf{3}$, respectively, which were easily separated by column chromatography to provide the product resulting from the selective $O$-alkylation of the less hindered hydroxyl group, i.e., 3, with a 75\% yield. The free hydroxyl group of 3 was then converted to the required triflate group by reaction with triflic anhydride in pyridine, giving the triflate 4 in $91 \%$ yield. The additional required coupling reactant, aryl boronic acid 6, was prepared from the orcinol-derived bromide 5 [23] by halogen-metal exchange using butyllithium and reaction of the resulting lithiated derivative with triisopropyl borate.

The subsequent palladium-catalyzed Suzuki-Miyaura coupling between the aryl triflate 4 and the labile boronic acid 6 gave the biaryl 7 in 75\% yield. Hydrolysis of the methoxymethyl ether (MOM) groups by treatment with methanolic $\mathrm{HCl}$, followed by intramolecular transesterification promoted by trifluoroacetic acid, completed the synthesis of the tricyclic benzochromenone backbone and afforded the methyl ester of hapten AL $a$, compound 8, in 97\% yield. To complete the synthesis of hapten AL a, only the hydrolysis of the methyl ester moiety of $\mathbf{8}$ was required, which was initially carried out under basic conditions ( $\mathrm{LiOH}$ in THF- $\mathrm{H}_{2} \mathrm{O}$ at room temperature, rt). However, under these conditions, the central lactone group of the benzochromenone core was partially opened, requiring acid treatment of the reaction crude to reconstruct the tricyclic ring system. It proved more convenient to carry out this transformation using enzymatic hydrolysis, so a lipase from Candida antarctica immobilized on an acrylic resin was used to hydrolyze the methyl ester group, providing hapten AL $\boldsymbol{a}$ in practically quantitative yield. 
<smiles>CC(=O)CCCCCOc1cc(OCCCCC(C)=O)c2c(c1)OC(C)(C)OC2=O</smiles>

$$
\begin{aligned}
& \text { 2: } \mathrm{R}=\left(\mathrm{CH}_{2}\right)_{4} \mathrm{CO}_{2} \mathrm{CH}_{3} \\
& \text { 3: } \mathrm{R}=\mathrm{H}
\end{aligned}
$$<smiles>CC(=O)CCCCOc1cc(O)c2c(=O)oc3cc(O)cc(C)c3c2c1</smiles>

8: $\mathrm{X}=\mathrm{OCH}_{3}$

$$
\left.\begin{array}{l}
\text { Hapten ALa: } X=\mathrm{OH} \\
\text { ALa-NHS: } X=\mathrm{ON}\left(\mathrm{COCH}_{2}\right)_{2}
\end{array}\right) \mathrm{g}
$$<smiles>[X]c1c(C)cc(OC)cc1OC</smiles>

Scheme 1. Synthesis of ALa-NHS ester. Reagents and conditions: (a) $\mathrm{Br}\left(\mathrm{CH}_{2}\right)_{4} \mathrm{CO}_{2} \mathrm{CH}_{3}, \mathrm{~K}_{2} \mathrm{CO}_{3}, \mathrm{KI}, \mathrm{Bu} 4 \mathrm{NBr}$, acetone, reflux, $16 \mathrm{~h}, 75 \%$ of 3 . (b) $\mathrm{Tf}_{2} \mathrm{O}$, pyridine, $0{ }^{\circ} \mathrm{C}$ to rt, $20 \mathrm{~h}, 91 \%$. (c) i. n-BuLi, $\mathrm{THF},-78{ }^{\circ} \mathrm{C}, 40 \mathrm{~min}$; ii. $\mathrm{B}\left(\mathrm{O}^{\mathrm{i}} \mathrm{Pr}\right)_{3},-78{ }^{\circ} \mathrm{C}$ to $0{ }^{\circ} \mathrm{C}, 1.5 \mathrm{~h}, 93 \%$. (d) $\mathrm{Pd}\left(\mathrm{PPh}_{3}\right)_{4}, \mathrm{~K}_{2} \mathrm{CO}_{3}, \mathrm{DMF}, 93{ }^{\circ} \mathrm{C}, 24 \mathrm{~h}, 75 \%$. (e) i. $\mathrm{HCl}, \mathrm{MeOH}, \mathrm{rt}, 22 \mathrm{~h}$; ii. TFA, $\mathrm{CH}_{2} \mathrm{Cl}_{2}, \mathrm{rt}, 20 \mathrm{~h}, 97 \%$. (f) Lipase acrylic resin, THF-PB 100 mM, rt, 20 h, 93\%. (g) EDC.HCl, NHS, DMF, rt, overnight, 99\% of crude product.

Upon completion of the synthesis of hapten $\mathrm{AL} \boldsymbol{a}$, its carboxylic group was activated by forming the corresponding $\mathrm{N}$-hydroxysuccinimidyl ester. This transformation was carried out under conventional activation conditions, with $N$-(3-dimethylaminopropyl)- $N^{\prime}$ ethylcarbodiimide hydrochloride (EDC. $\mathrm{HCl}$ ) and $\mathrm{N}$-hydroxisuccinimide (NHS) in $\mathrm{N}, \mathrm{N}$ dimethylformamide (DMF) at rt, yielding the corresponding $N$-hydroxysuccinimidyl ester, AL $a$-NHS, in good yield. The activated hapten was extracted essentially pure from the reaction as judged by ${ }^{1} \mathrm{H}$ NMR, so it was further used without additional purification by column chromatography. NMR spectra of all of the intermediates and the hapten can be found in the Supplementary Materials file.

Hapten $\mathbf{A} \mathbf{L} \boldsymbol{b}$ was synthesized following a similar procedure as hapten AL $\boldsymbol{a}$, except that in this case the tricyclic benzochromenone core was built first, with the hydroxyl groups appropriately protected to allow subsequent incorporation of the spacer arm at the required C-3 position. As shown in Scheme 2, the synthesis of the benzochromenone ring system began with the palladium-catalyzed cross-coupling reaction between the aryl boronic acid $\mathbf{6}$ and the previously reported bromobenzaldehyde 9 [24,25]. This coupling was carried out under conditions similar to those previously used for the conversion of 4 and 6 into 7, obtaining the biphenyl-2-carbaldehyde 10 in 77\% yield. The formyl group was further oxidized to the carboxylic group under Pinnick oxidation conditions to afford the biphenyl-2-carboxylic acid 11, which was then treated with methanolic $\mathrm{HCl}$ at $55{ }^{\circ} \mathrm{C}$ to promote deprotection of the MOM groups and further intramolecular esterification, thus completing the formation of the tricyclic benzochromenone system. Under these conditions, both sequential processes worked extremely well, affording $\mathbf{1 2}$ in practically quantitative yield. O-alkylation of the phenol-like hydroxyl group at the C-3 position of $\mathbf{1 2}$ with methyl 5-bromovalerate, using $\mathrm{Cs}_{2} \mathrm{CO}_{3}$ in DMF as base, gave the $O$-alkylated derivative 13 in $94 \%$ yield. The methyl ester of $\mathbf{1 3}$ was further converted to the corresponding carboxylic group under enzymatic hydrolytic conditions, yielding 14 also in high yield. The hapten $\mathbf{A} \mathbf{b} \boldsymbol{b}$ was first obtained by hydrogenolysis of both benzyl ether groups of $\mathbf{1 4}$ using $5 \% \mathrm{Pd}$ 
on activated carbon as catalyst. With hapten AL $\boldsymbol{b}$ in hand, we activated the carboxylic group using the carbodiimide-NHS procedure as was done for hapten AL $a$. However, the overall yield from these two processes was low, most likely motivated by an intermolecular esterification reaction between a hydroxyl group and the aliphatic active ester that resulted in the spontaneous formation of a transparent thin film, a polyester polymer, on the flask walls. By reversing the order of these steps, i.e., by activating the carboxylic group first and then releasing the hydroxyl groups, a much better result was obtained. Thus, treatment of carboxylic acid 14 with EDC and NHS as before, followed by hydrogenolysis of the benzyl ether moieties of the resulting $N$-hydroxysuccinimidyl ester 15 with $5 \% \mathrm{Pd}$ on activated carbon in acetone, gave the desired $N$-hydroxysuccinimidyl ester of hapten ALb, AL $b$-NHS ester, with a very high overall yield. As in the case of the active ester of hapten AL $\boldsymbol{a}$, the AL $\boldsymbol{b}$-NHS ester was extracted essentially pure from the reaction as judged by ${ }^{1} \mathrm{H}$ NMR, so it was further used without additional purification by column chromatography. NMR spectra of all of the intermediates and the hapten can be found in the Supplementary Materials file.<smiles>COc1cc(C)c(Br)c(OCC(C)C)c1</smiles>

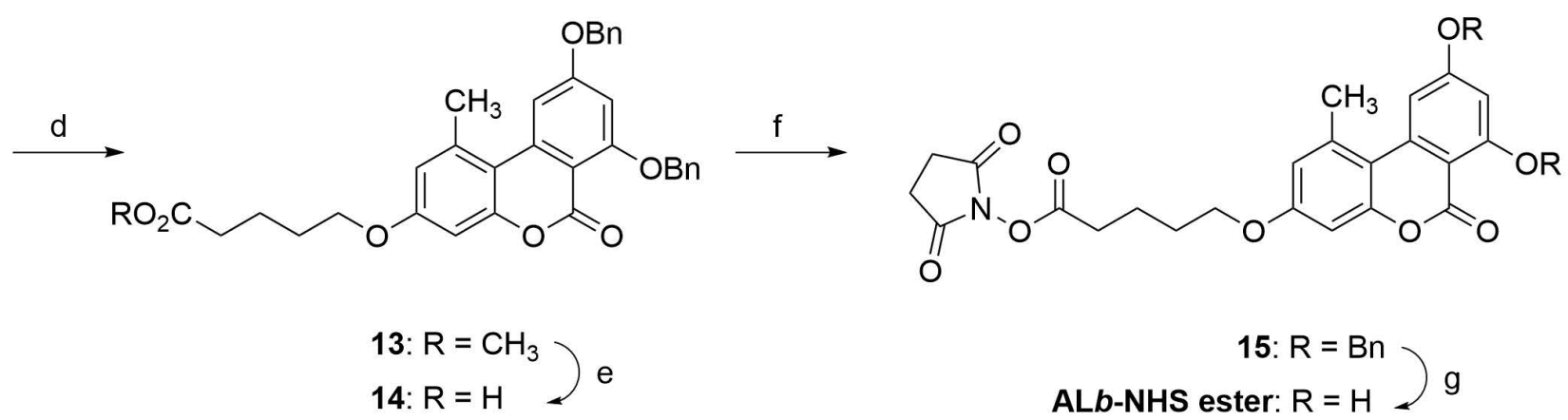

Scheme 2. Synthesis of ALb-NHS ester. Reagents and conditions: (a) $\mathrm{Pd}\left(\mathrm{PPh}_{3}\right)_{4}, \mathrm{~K}_{2} \mathrm{CO}_{3}, \mathrm{DMF}, 95{ }^{\circ} \mathrm{C}, 19 \mathrm{~h}, 77 \%$. (b) $\mathrm{NaH}_{2} \mathrm{PO}_{4} \cdot \mathrm{H}_{2} \mathrm{O}, \mathrm{NaClO}_{2},{ }^{\mathrm{t}} \mathrm{BuOH}-\mathrm{H}_{2} \mathrm{O}(5: 1), \mathrm{rt}, 5 \mathrm{~h}, 96 \%$. (c) ${ }^{\mathrm{i}} \mathrm{PrOH}, \mathrm{THF}, \mathrm{conc} \mathrm{HCl}, 55^{\circ} \mathrm{C}, 24 \mathrm{~h}, 98 \%$. (d) $\mathrm{Br}_{(}\left(\mathrm{CH}_{2}\right)_{4} \mathrm{CO}_{2} \mathrm{CH}_{3}$, $\mathrm{Cs}_{2} \mathrm{CO}_{3}$, DMF, 94\%. (e) Lipase acrylic resin, THF-PB $100 \mathrm{mM}, \mathrm{rt}, 20 \mathrm{~h}, 99 \%$. (f) EDC.HCl, NHS, DMF, rt, overnight. (g) 5\% $\mathrm{Pd} / \mathrm{C}$, acetone, $\mathrm{H}_{2}$ (1.5 atm), rt, $19 \mathrm{~h}, 95 \%$ of crude product from 14.

\subsection{Bioconjugate Preparation}

Bioconjugates of haptens $\mathbf{A} \mathbf{L} \boldsymbol{a}$ and $\mathbf{A} \mathbf{L} \boldsymbol{b}$ were prepared by the active ester method. The activated haptens were dissolved in dimethyl sulfoxide (DMSO) instead of DMF to improve the solubility. Moreover, the number of hapten equivalents required for efficiently labelling the studied proteins was higher than usual. Commonly, 20-fold hapten-to-protein molar excess for bovine serum albumin (BSA), and 10-fold excess for ovalbumin (OVA) and horseradish peroxidase (HRP) are usually employed in our laboratory. For these haptens, 40-fold and 15-fold excess was used for BSA and HRP conjugates, respectively. Moreover, extremely slow addition of the hapten over the protein solution was required. These concentrations and procedures were necessary, probably due to low hapten solubility in buffer and potential intermolecular polymerization reactions that inactivate the hapten. The obtained bioconjugates were purified by size-exclusion chromatography and characterized 
by matrix-assisted laser desorption ionization time-of-flight mass spectrometry (MALDITOF/MS) analysis. The two BSA conjugates had similar hapten densities, with haptento-protein molar ratios of 15.2 and 18.6 for BSA-AL $\boldsymbol{a}$ and BSA-AL $\boldsymbol{b}$, respectively, which is considered optimal for immunogens-excessive molar ratios could lead to low protein solubility, and higher or lower hapten densities could be counter-productive for highaffinity antibody generation. Regarding ovalbumin (OVA) conjugates, molar ratios were lower than those of BSA conjugates-around 3 for both haptens -, as it is desirable for coating conjugates to enhance the competitive reaction with the target analyte. Finally, the hapten densities of the enzyme tracers were estimated to be 2.0 and 2.2 for haptens AL $a$ and $\mathbf{A L} \boldsymbol{b}$, respectively, which is within the expected range for HRP conjugates. The MALDI spectra of the prepared bioconjugates can be seen in Figure 2.
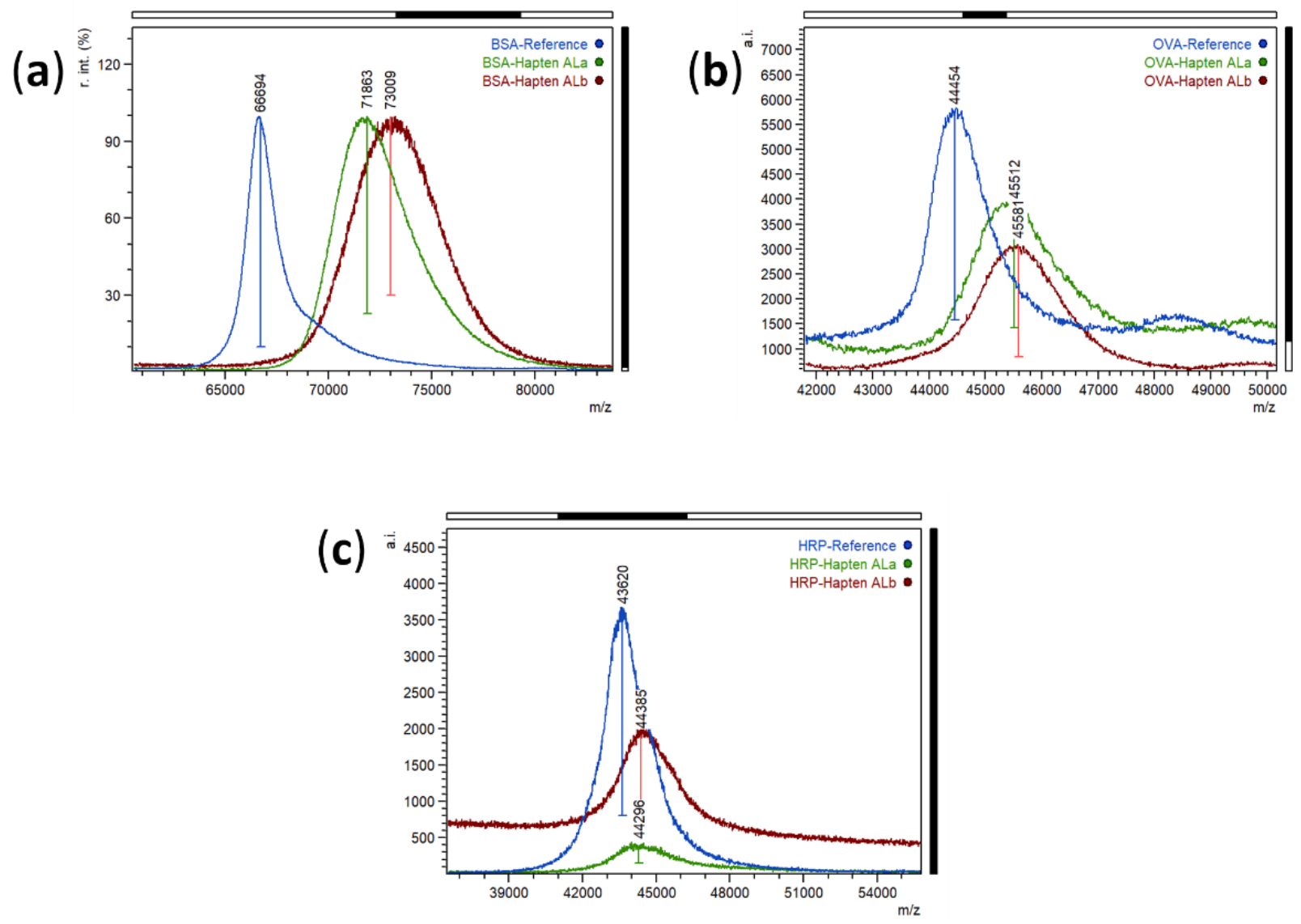

Figure 2. MALDI-TOF mass spectra (singly charged ions) of proteins (blue) and bioconjugates with hapten AL $a$ (green) and hapten ALb (brick-red). (a) Normalized spectra of BSA and BSA conjugates, (b) Spectra of OVA and OVA conjugates, and (c) Spectra of HRP and HRP conjugates.

\subsection{Assessment of the Immune Response}

Four polyclonal antibodies were generated in this study, two from each BSA-hapten conjugate. To evaluate the immune response to the prepared synthetic haptens, binding of the antibodies to the homologous conjugate-the conjugate with the same hapten that was used to generate the corresponding antibody-was studied by checkerboard competitive ELISA, using the direct and the indirect assay formats.

Concerning direct assays, the $\mathrm{IC}_{50}$ values for $\mathrm{AOH}$ of the obtained antibodies were in the low nanomolar range (Table 1). ALa-type antibodies showed equal or similar $\mathrm{IC}_{50}$ values for $\mathrm{AOH}$ and AME. In particular, antibody ALa\#1 showed very high affinity$\mathrm{IC}_{50}$ values were $2.2 \mathrm{nM}$-for both mycotoxins, and the cross-reactivity (CR) values of antibodies ALa\#1 and ALa\#2 for AME were 100\% and 199\%, respectively. These are the first reported polyclonal antibodies with equivalent recognition to both Alternaria toxins. 
To date, only one monoclonal antibody with such specificity has been published [15]. In contrast, ALb-type antibodies bound AOH with high affinity, but their recognition for AME was negligible $-\mathrm{CR}$ values were below $1 \%$ (Table 1 ). The $\mathrm{IC}_{50}$ values to $\mathrm{AOH}$ of these specific antibodies were $1.2 \mathrm{nM}$, an affinity comparable to that of previously published polyclonal antibodies $[11,13,16]$. The position of the spacer arm in hapten AL $\boldsymbol{a}$ provided a closer mimic of the alkylated hydroxyl group of AME (C-9 position), whereas in hapten $\mathbf{A L} \boldsymbol{b}$ the hydroxyl groups at C-7 and C-9 were unsubstituted, as in the molecule of $\mathrm{AOH}$ (Figure 1). Therefore, display of the hydroxyl group at C-9 was maximized in hapten ALb, which explains the much lower affinity of ALb-type antibodies for AME compared to $\mathrm{AOH}$.

Table 1. Antibody characterization by checkerboard direct and indirect competitive ELISA using the corresponding homologous conjugate $(n=3)^{\text {a }}$.

\begin{tabular}{|c|c|c|c|c|c|c|c|c|c|c|}
\hline \multirow[b]{3}{*}{$\mathrm{pAb}$} & \multicolumn{10}{|c|}{ Assay Conjugate } \\
\hline & \multicolumn{5}{|c|}{ Direct Assay } & \multicolumn{5}{|c|}{ Indirect Assay } \\
\hline & {$[p \mathrm{Ab}]^{\mathbf{b}}$} & {$[\mathrm{HRP}]^{\mathrm{c}}$} & $\begin{array}{c}\mathrm{IC}_{50} \mathrm{~d} \\
\mathrm{AOH}\end{array}$ & $\begin{array}{l}\text { IC }_{50} \\
\text { AME }\end{array}$ & $\mathrm{CR}^{\mathrm{e}}(\%)$ & {$[\mathrm{pAb}]$} & [OVA] & $\begin{array}{l}\mathrm{IC}_{50} \\
\mathrm{AOH}\end{array}$ & $\begin{array}{c}\mathrm{IC}_{50} \\
\mathrm{AME}\end{array}$ & $\begin{array}{l}\text { CR } \\
(\%)\end{array}$ \\
\hline ALa\#1 & 10 & 10 & 2.20 & 2.20 & 100 & 100 & 100 & 6.28 & 3.08 & 204 \\
\hline ALa\#2 & 10 & 10 & 7.61 & 3.83 & 199 & 10 & 10 & 36.2 & 8.18 & 442 \\
\hline $\mathrm{AL} b \# 1$ & 10 & 10 & 1.19 & 170 & 0.70 & 100 & 100 & 6.23 & 402 & 1.55 \\
\hline $\mathrm{AL} b \# 2$ & 10 & 10 & 1.19 & 218 & 0.55 & 300 & 100 & 27.5 & 403 & 6.82 \\
\hline
\end{tabular}

${ }^{a}$ The $A_{\max }$ values were higher than 1.0. ${ }^{b}$ Dilution factor $\times 10^{-3} .{ }^{c}$ Bioconjugate concentration in ng $/ \mathrm{mL} .{ }^{\mathrm{d}}$ Values are in nM. ${ }^{\mathrm{e}}$ Crossreactivity values with $\mathrm{AOH}$ as reference.

Regarding the indirect assay format, the four antibodies bound the corresponding homologous coating conjugate. As observed with the direct format, the AL $a$-derived antibodies recognized $\mathrm{AOH}$ and $\mathrm{AME}$, whereas the $\mathrm{AL} b$-derived antibodies were more specific to $\mathrm{AOH}$ (Table 1 ). The $\mathrm{IC}_{50}$ values were consistent with previously published results for indirect competitive ELISA with polyclonal antibodies $[10,11,16]$. Our strategy to prepare immunizing haptens with opposite linker tethering sites clearly demonstrated that the linker position strongly determines the specificity of antibodies to these Alternaria mycotoxins.

\subsection{Assessment of Heterologous Conjugates}

Heterologous conjugates constitute a well-known strategy for improving the sensitivity of immunoassays. To further characterize the generated antibodies, competitive assays were carried out using the heterologous conjugate, i.e., assay conjugates of haptens $\mathrm{AL} a$ and $\mathrm{AL} \boldsymbol{b}$ for $\mathrm{AL} b$ - and ALa-type antibodies, respectively. In the direct assay format, low binding to the heterologous tracer-with the linker on the opposite side of the $\mathrm{AOH}$ molecule compared to the immunizing conjugate-was observed $\left(\mathrm{A}_{\max }\right.$ values were below 0.6). In contrast, the change in the linker attachment site was not detrimental to hapten recognition in the indirect format, as the four antibodies bound the corresponding heterologous coating conjugate (Table 2). Reasonably, higher antibody and/or conjugate concentrations were required with the heterologous conjugates to reach sufficient signal. The obtained $\mathrm{IC}_{50}$ values using the heterologous coating conjugate were mostly lower than those obtained with the homologous assays. Anyway, CR values did not significantly change with heterologous conjugates. 
Table 2. Antibody characterization by checkerboard indirect competitive ELISA using the corresponding heterologous coating conjugate $(n=3)^{\text {a }}$.

\begin{tabular}{cccccc}
\hline $\mathbf{p A b}$ & {$[\mathbf{p A b}]^{\mathbf{b}}$} & ${\text { [OVA }]^{\mathbf{c}}}^{\mathbf{b}}$ & $\mathbf{I C}_{\mathbf{5 0}}{ }^{\mathbf{d}} \mathbf{A O H}$ & $\mathbf{I C}_{\mathbf{5 0}}$ AME & CR (\%) \\
\hline ALa\#1 & 20 & 100 & 3.83 & 6.06 & 63.2 \\
ALa\#2 & 10 & 100 & 11.2 & 2.80 & 400 \\
& & & & & \\
ALb\#1 & 20 & 1000 & 3.32 & 230 & 1.44 \\
ALb\#2 & 30 & 1000 & 13.4 & 168 & 7.98
\end{tabular}

${ }^{\mathrm{a}}$ The $\mathrm{A}_{\max }$ values were higher than 1.0. ${ }^{\mathrm{b}}$ Dilution factor $\times 10^{-3} .{ }^{\mathrm{c}}$ Bioconjugate concentration in $\mathrm{ng} / \mathrm{mL} .{ }^{\mathrm{d}}$ Values are in $\mathrm{nM}$.

\section{Conclusions}

In this study, two de novo synthesized and purified $\mathrm{AOH}$ haptens were comprehensively characterized by spectrometric methods, and bioconjugates with unique structure and composition were prepared for the first time. In this perspective, it is worth noting the challenges of obtaining stable enzyme tracers with high activity. This matter was most likely caused by the chemical characteristics of Alternaria toxins and their haptens, which could explain why no direct competitive immunoassays for these mycotoxins have been reported up to now. Once this issue was overcome, the resultant immunoreagents were thoroughly investigated utilizing both direct and indirect competitive ELISA, as well as homologous and heterologous conjugates. Remarkably, antibodies capable of binding $\mathrm{AOH}$ and $\mathrm{AME}$ with affinities in the low nanomolar range were eventually generated from both haptens. Given that the levels of these mycotoxins are not yet regulated, both specific and generic antibodies are relevant. Our findings showed that hapten AL $\boldsymbol{a}$, with the linker at the methylated hydroxyl group in AME (C-9 position), was particularly well-suited for producing antibodies that recognized similarly both toxins, whereas antibodies generated from hapten $\mathbf{A} \mathbf{L} \boldsymbol{b}$, with the spacer arm at the hydroxyl group in C-3 position, primarily bound $\mathrm{AOH}$. In contrast to previous one-pot hapten synthesis and bioconjugation procedures, the strategy described here for producing $\mathrm{AOH}$ haptens with alternative linker tethering sites not only enabled high-affinity antibodies with different specificities, but it may also help to improve the sensitivity of immunoassays to Alternaria mycotoxins by using site heterologous haptens.

\section{Materials and Methods}

\subsection{Reagents and Instruments}

Standard AOH [3,7,9-trihydroxy-1-methyl-benzo[c]chromen-6-one, CAS registry number 641-38-3, Mw 258.23] and AME [3,7-dihydroxy-9-methoxy-1-methyl-benzo[c]chromen6-one, CAS registry number 23452-05-3, Mw 272.25] from Alternaria sp. were purchased from Merck (Darmstadt, Germany). Mycotoxins were dissolved in anhydrous $N, N$ dimethylformamide (DMF), and the stock solutions were stored at $-20^{\circ} \mathrm{C}$. Phosphate buffered saline (PBS) 10 $\times$ solution (Fisher BioReagents BP399-20) was from Thermo Fisher Scientific (Waltham, MA, USA). Immunizing bioconjugates were prepared with BSA, fraction V, obtained from Roche Applied Science (Mannheim, Germany). OVA, HRP, Freund's adjuvants, and adult bovine serum, were acquired from Merck (Darmstadt, Germany). Polyclonal goat anti-rabbit (GAR) immunoglobulins antibody and polyclonal goat antirabbit immunoglobulins antibody conjugated to peroxidase (GAR-HRP) were purchased from Rockland Immunochemicals Inc. (Pottstown, PA, USA) and BioRad (Madrid, Spain), respectively. 3,3',5,5'-Tetramethylbenzidine (TMB) liquid substrate for ELISA was obtained from Biopanda Reagents Ltd. (Belfast, UK). Other reagents, materials, and instruments employed for bioconjugate preparation and ELISA experiments are described in the Supplementary Materials file. 


\subsection{Synthesis of the N-hydroxysuccinimidyl Ester of Hapten $A L a$}

4.2.1. Preparation of methyl 5-((5-hydroxy-2,2-dimethyl-4-oxo-4H-benzo[d][1,3]dioxin7-yl)oxy)pentanoate (3)

Methyl 5-bromovalerate ( $186 \mu \mathrm{L}, 266 \mathrm{mg}, 1.36 \mathrm{mmol}, 1.1$ equiv) was added to a solution of 1,3-benzodioxinone 1 ( $260 \mathrm{mg}, 1.237 \mathrm{mmol}), \mathrm{KI}(83 \mathrm{mg}, 0.500 \mathrm{mmol}, 0.4$ equiv), $\mathrm{Bu}_{4} \mathrm{NBr}(0.5 \mathrm{mg}, 1.6 \mu \mathrm{mol})$ y $\mathrm{K}_{2} \mathrm{CO}_{3}(188 \mathrm{mg}, 1.36 \mathrm{mmol}, 1$ equiv) in dry acetone $(9 \mathrm{~mL})$ under nitrogen. After heating the mixture at reflux for $16 \mathrm{~h}$, the acetone was eliminated at reduced pressure and the resulting brownish residue was diluted with water and extracted with $\mathrm{Et}_{2} \mathrm{O}$. The combined organic layers were washed with water and brine, dried over anhydrous $\mathrm{MgSO}_{4}$ and concentrated under vacuum. The obtained crude product was purified by chromatography on silica gel, using hexane-EtOAc mixtures from 9:1 to 7:3 as eluent, to afford, in order of elution, dialkylated derivative $2(67.7 \mathrm{mg}, 12.5 \%)$ and monoalkylated compound $3\left(300 \mathrm{mg}, 75 \%\right.$ ) as a white solid. Mp $97.3-98.2^{\circ} \mathrm{C}$ (crystallized from hexane-EtOAc) IR (ATR) $v_{\max }\left(\mathrm{cm}^{-1}\right) 3017$ (w), 1740 (s), 1672 (s), 1251 (s), 1159 (s), 840 (s), 794 (s); ${ }^{1} \mathrm{H}$ NMR (300 MHz, $\left.\mathrm{CDCl}_{3}\right) \delta 10.42(\mathrm{~s}, 1 \mathrm{H}, \mathrm{OH}), 6.11(\mathrm{~d}, J=2.2 \mathrm{~Hz}, 1 \mathrm{H}$, $\mathrm{H}-6), 5.97(\mathrm{~d}, J=2.2 \mathrm{~Hz}, 1 \mathrm{H}, \mathrm{H}-8), 3.98\left(\mathrm{t}, J=5.8 \mathrm{~Hz}, 2 \mathrm{H}, \mathrm{H}_{2}-5\right), 3.68\left(\mathrm{~s}, 3 \mathrm{H}, \mathrm{OCH}_{3}\right), 2.39(\mathrm{t}$, $\left.J=7.0 \mathrm{~Hz}, 2 \mathrm{H}, \mathrm{H}_{2}-2\right), 1.81\left(\mathrm{~m}, 4 \mathrm{H}, \mathrm{H}_{2}-3\right.$ and $\left.\mathrm{H}_{2}-4\right), 1.72\left(\mathrm{~s}, 6 \mathrm{H}, 2 \times \mathrm{CH}_{3}\right) ;{ }^{13} \mathrm{C} \mathrm{NMR}(75 \mathrm{MHz}$, $\left.\mathrm{CDCl}_{3}\right) \delta 173.8\left(\mathrm{CO}_{2} \mathrm{CH}_{3}\right), 167.2(\mathrm{CO}), 165.3(\mathrm{C}-7), 163.2(\mathrm{C}-8 \mathrm{a}), 156.9$ (C-5), $107.0(\mathrm{C}-2)$, $96.3(\mathrm{CH}-6), 95.1(\mathrm{CH}-8), 93.1(\mathrm{C}-4 \mathrm{a}), 68.1\left(\mathrm{CH}_{2}-5\right), 51.7\left(\mathrm{OCH}_{3}\right), 33.7\left(\mathrm{CH}_{2}-2\right), 28.4\left(\mathrm{CH}_{2}-4\right)$, $25.8\left(2 \times \mathrm{CH}_{3}\right), 21.6\left(\mathrm{CH}_{2}-3\right)$; HRMS (TOF MS ES+) $\mathrm{m} / z$ calculated for $\mathrm{C}_{16} \mathrm{H}_{20} \mathrm{O}_{7}[\mathrm{M}+\mathrm{H}]^{+}$ 325.1282 , found 325.1283 .

4.2.2. Preparation of methyl 5-((2,2-dimethyl-4-oxo-5-((trifluoromethyl)sulfonyl)oxy)-4Hbenzo[d][1,3]dioxin-7-yl)oxy)pentanoate (4)

Triflic anhydride ( $230 \mu \mathrm{L}, 1.369 \mathrm{mmol}, 1.5$ equiv) was added to a solution of phenol 3 $(296 \mathrm{mg}, 0.913 \mathrm{mmol})$ in anhydrous pyridine $(4.5 \mathrm{~mL})$ at $0{ }^{\circ} \mathrm{C}$ under nitrogen. The reaction mixture was allowed to warm to rt and stirred for $20 \mathrm{~h}$, then cooled down to $0{ }^{\circ} \mathrm{C}$ and treated with a saturated aqueous solution of $\mathrm{NaHCO}_{3}$, stirred for a few minutes at $\mathrm{rt}$ and then extracted with $\mathrm{Et}_{2} \mathrm{O}$. The organic layers were washed with water, a $1 \%(w / v)$ aqueous solution of $\mathrm{CuSO}_{4}$ and brine, dried over anhydrous $\mathrm{MgSO}_{4}$ and concentrated at reduced pressure. The obtained residue was chromatographed on silica gel, using hexane-EtOAc mixtures from 9:1 to 8:2 as eluent, to give aryl triflate $4(378.8 \mathrm{mg}, 91 \%)$ as a white semisolid. IR (ATR) $v_{\max }\left(\mathrm{cm}^{-1}\right) 3114(\mathrm{w}), 1746(\mathrm{~s}), 1733$ (s), 1381 (s), 1228 (s), 1167 (s), 869 (s); ${ }^{1} \mathrm{H}$ NMR (300 MHz, CDCl $\left.)_{3}\right) \delta 6.51(\mathrm{~d}, J=2.3 \mathrm{~Hz}, 1 \mathrm{H}, \mathrm{H}-6), 6.45(\mathrm{~d}, J=2.3 \mathrm{~Hz}, 1 \mathrm{H}, \mathrm{H}-8), 4.02(\mathrm{t}$, $\left.J=5.8 \mathrm{~Hz}, 2 \mathrm{H}, \mathrm{H}_{2}-5\right), 3.68\left(\mathrm{~s}, 3 \mathrm{H}, \mathrm{CO}_{2} \mathrm{CH}_{3}\right), 2.40\left(\mathrm{t}, J=6.9 \mathrm{~Hz}, 2 \mathrm{H}, \mathrm{H}_{2}-2\right), 1.85\left(\mathrm{~m}, 4 \mathrm{H}, \mathrm{H}_{2}-3\right.$ and $\left.\mathrm{H}_{2}-4\right), 1.73\left(\mathrm{~s}, 6 \mathrm{H}, 2 \times \mathrm{CH}_{3}\right) ;{ }^{13} \mathrm{C}$ NMR $\left(75 \mathrm{MHz}, \mathrm{CDCl}_{3}\right) \delta 173.7\left(\mathrm{CO}_{2} \mathrm{CH}_{3}\right), 165.0(\mathrm{CO})$, 158.9 (C-7), 157.2 (C-8a), 150.1 (C-5), 106.7 (C-2), 105.7 (CH-6), 101.6 (CH-8), 101.0 (C-4a), $68.9\left(\mathrm{CH}_{2}-5\right), 51.8\left(\mathrm{OCH}_{3}\right), 33.6\left(\mathrm{CH}_{2}-2\right), 28.3\left(\mathrm{CH}_{2}-4\right), 25.7\left(2 \times \mathrm{CH}_{3}\right), 21.5\left(\mathrm{CH}_{2}-3\right) ;{ }^{19} \mathrm{~F}$ NMR $\left(282 \mathrm{MHz}, \mathrm{CDCl}_{3}\right) \delta 73.1\left(\mathrm{~s}, \mathrm{CF}_{3}\right) ; \mathrm{HRMS}$ (TOF, ES+) $\mathrm{m} / \mathrm{z}$ calculated for $\mathrm{C}_{17} \mathrm{H}_{23} \mathrm{~F}_{3} \mathrm{NO}_{9} \mathrm{~S}[\mathrm{M}+$ $\left.\mathrm{NH}_{4}\right]^{+}$474.1040; found 474.1027.

4.2.3. Preparation of methyl 5-((5-(2,4-bis(methoxymethoxy)-6-methylphenyl)-2,2dimethyl-4-oxo-4H-benzo[d][1,3]dioxin-7-yl)oxy)pentanoate (7)

(i) Preparation of boronic acid 6. A solution of $n$-BuLi in hexane $(1.3 \mathrm{M}, 336 \mu \mathrm{L}$, $0.436 \mathrm{mmol}, 1.05$ equiv) was dropwise added to a solution of aryl bromide 5 (122.3 $\mathrm{mg}$, $0.420 \mathrm{mmol})$ in anhydrous THF $(2.5 \mathrm{~mL})$ at $-78^{\circ} \mathrm{C}$ under nitrogen. The reaction mixture was stirred at this temperature for $40 \mathrm{~min}, \mathrm{~B}\left(\mathrm{O}^{i} \mathrm{Pr}\right)_{3}(322 \mu \mathrm{L}, 1.386 \mathrm{mmol}, 3.3$ equiv) was then added and the mixture stirred for $1.5 \mathrm{~h}$. After this time, the dry ice bath was replaced by an ice bath and the mixture treated with an aqueous saturated solution of $\mathrm{NH}_{4} \mathrm{Cl}$ $(0.7 \mathrm{~mL})$, then diluted with water and extracted with $\mathrm{Et}_{2} \mathrm{O}$. The organic layers were washed with brine, dried over anhydrous $\mathrm{Na}_{2} \mathrm{SO}_{4}$ and concentrated under reduced pressure to give boronic acid $6(100.0 \mathrm{mg}, 93 \%)$ as a thick oil that was immediately used in the next reaction without further purification since it is relatively prone to protodeboronation [26]. ${ }^{1} \mathrm{H}$ NMR (300 MHz, DMSO-d $\left.)_{6}\right) \delta 7.91(\mathrm{~s}, 1 \mathrm{H}, \mathrm{BOH}), 6.49(\mathrm{~d}, J=2.1 \mathrm{~Hz}, 1 \mathrm{H}, \mathrm{H}-4), 6.47$ (d, 
$J=2.10 \mathrm{~Hz}, 1 \mathrm{H}, \mathrm{H}-6$ ), 5.12 and 5.09 (each s, $2 \mathrm{H}$ each, $2 \times \mathrm{OCH}_{2} \mathrm{O}$ ), 3.37 and 3.34 (each s, $3 \mathrm{H}$ each, $\left.2 \times \mathrm{OCH}_{3}\right), 2.20\left(\mathrm{~s}, 3 \mathrm{H}, \mathrm{CH}_{3}\right)$.

(ii) Coupling reaction between aryl triflate 4 and boronic acid 6. A mixture of the above obtained boronic acid 6 ( $47.4 \mathrm{mg}, 0.185 \mathrm{mmol})$, aryl triflate $4(41.6 \mathrm{mg}, 0.091 \mathrm{mmol})$, powdered $\mathrm{K}_{2} \mathrm{CO}_{3}(43.2 \mathrm{mg}, 0.312 \mathrm{mmol})$ and $\mathrm{Pd}\left(\mathrm{PPh}_{3}\right)_{4}(11.4 \mathrm{mg}, 9.9 \mu \mathrm{mol})$ under nitrogen was dissolved in anhydrous DMF $(1.2 \mathrm{~mL})$, previously degassed by three freeze-vacuumthaw cycles. The mixture was heated at $93^{\circ} \mathrm{C}$ and stirred at this temperature for $24 \mathrm{~h}$. The mixture was cooled to rt, quenched with water and extracted with EtOAc. The combined organic layers were successively washed with water, a $1.5 \%(w / v)$ aqueous solution of $\mathrm{LiCl}$ and brine, and dried over anhydrous $\mathrm{MgSO}_{4}$. The obtained residue after evaporation of the solvent was chromatographed on silica gel, using hexane-EtOAc 8:2 as eluent, to afford biaryl compound $7(35.2 \mathrm{mg}, 75 \%)$ as a yellowish oil. ${ }^{1} \mathrm{H}$ NMR $\left(300 \mathrm{MHz}, \mathrm{CDCl}_{3}\right) \delta 6.71$ $(\mathrm{d}, J=2.3 \mathrm{~Hz}, 1 \mathrm{H}, \mathrm{H}-6), 6.64(\mathrm{~d}, J=2.3 \mathrm{~Hz}, 1 \mathrm{H}, \mathrm{H}-8), 6.42(\mathrm{~d}, J=2.5 \mathrm{~Hz}, 1 \mathrm{H}, \mathrm{H}-5), 6.40$ (d, $J=2.5 \mathrm{~Hz}, 1 \mathrm{H}, \mathrm{H}-3), 5.18\left(\mathrm{AB}\right.$ system, $\left.J=6.7 \mathrm{~Hz}, 2 \mathrm{H}, \mathrm{OCH}_{2} \mathrm{O}\right), 4.98(\mathrm{AB}$ system, $J=6.6 \mathrm{~Hz}$ $\left.2 \mathrm{H}, \mathrm{OCH}_{2} \mathrm{O}\right), 3.99\left(\mathrm{t}, J=5.6 \mathrm{~Hz}, 2 \mathrm{H}, \mathrm{H}_{2}-5\right), 3.67\left(\mathrm{~s}, 3 \mathrm{H}, \mathrm{CO}_{2} \mathrm{CH}_{3}\right), 3.50$ and 3.29 (each $\mathrm{s}$, $3 \mathrm{H}$ each, $\left.2 \times \mathrm{OCH}_{3}\right), 2.39\left(\mathrm{t}, J=6.8 \mathrm{~Hz}, 2 \mathrm{H}, \mathrm{H}_{2}-2\right), 2.04\left(\mathrm{~s}, 3 \mathrm{H}, \mathrm{CH}_{3} \mathrm{Ph}\right), 1.81\left(\mathrm{~m}, 4 \mathrm{H}, \mathrm{H}_{2}-3\right.$ and $\left.\mathrm{H}_{2}-4\right), 1.71\left(\mathrm{~s}, 6 \mathrm{H}, 2 \times \mathrm{CH}_{3}\right) ;{ }^{13} \mathrm{C} \mathrm{NMR}\left(75 \mathrm{MHz}, \mathrm{CDCl}_{3}\right) \delta 173.9\left(\mathrm{CO}_{2} \mathrm{CH}_{3}\right), 164.1(\mathrm{CO})$, 159.2 (C-7), 158. 5 (C-8a), 157.4 (C-4), 154.8 (OC-2), 142.9 (C-6), 136.9 (C-5), 123.9 (C-1), 113.8 (CH-3), $110.6(\mathrm{CH}-8), 106.8(\mathrm{C}-2), 105.1(\mathrm{CH}-5), 101.2(\mathrm{CH}-6), 94.9$ and $94.7\left(2 \times \mathrm{OCH}_{2} \mathrm{O}\right)$, $68.1\left(\mathrm{CH}_{2}-5\right), 56.3$ and $55.9\left(2 \times \mathrm{OCH}_{3}\right), 51.8\left(\mathrm{CO}_{2} \mathrm{CH}_{3}\right), 33.7\left(\mathrm{CH}_{2}-2\right), 28.6\left(\mathrm{CH}_{2}-4\right), 26.3$ and $25.2\left(2 \times \mathrm{CH}_{3}\right), 21.7\left(\mathrm{CH}_{2}-3\right), 20.7\left(\mathrm{CH}_{3} \mathrm{Ph}\right)$. HRMS (TOF, ES+) $\mathrm{m} / z$ calculated for $\mathrm{C}_{27} \mathrm{H}_{34} \mathrm{O}_{10}$ $[\mathrm{M}+\mathrm{H}]^{+}$519.2225; found 519.2212.

4.2.4. Preparation of methyl 5-((3,7-dihydroxy-1-methyl-6-oxo-6H-benzo[c]chromen-9-yl) oxy)pentanoate (8)

A $3 \mathrm{M}$ solution of $\mathrm{HCl}$ in $\mathrm{MeOH}(150 \mu \mathrm{L}, 0.450 \mathrm{mmol})$ was added to a solution of biaryl compound $7(26.1 \mathrm{mg}, 0.050 \mathrm{mmol})$ in anhydrous $\mathrm{MeOH}(1.5 \mathrm{~mL})$ and the reaction mixture was stirred at $\mathrm{rt}$ for $22 \mathrm{~h}$. After concentration under vacuum, the residue was dissolved in anhydrous $\mathrm{CH}_{2} \mathrm{Cl}_{2}(4 \mathrm{~mL})$ and treated with trifluoroacetic acid $(430 \mu \mathrm{L})$. Following stirring for $20 \mathrm{~h}$ at rt, thin layer chromatography showed the formation of a single compound and all the volatiles were removed under vacuum, using $\mathrm{CHCl}_{3}$ to co-evaporate the last traces of TFA. The obtained residue was purified by chromatography, using $\mathrm{CHCl}_{3}$ as eluent, to give benzochromenone derivative $8(18.1 \mathrm{mg}, 97 \%)$ as a white solid. ${ }^{1} \mathrm{H} \mathrm{NMR}(300 \mathrm{MHz}$, DMSO- $\left.d_{6}\right) \delta 11.79$ and 10.33 (each s, $1 \mathrm{H}$ each, $\left.2 \times \mathrm{OH}\right), 7.13(\mathrm{~d}, J=2.2 \mathrm{~Hz}, 1 \mathrm{H}, \mathrm{H}-10), 6.69$ $(\mathrm{d}, J=2.6 \mathrm{~Hz}, 1 \mathrm{H}, \mathrm{H}-2), 6.61(\mathrm{~d}, J=2.6 \mathrm{~Hz}, 1 \mathrm{H}, \mathrm{H}-4), 6.55(\mathrm{~d}, J=2.2 \mathrm{~Hz}, 1 \mathrm{H}, \mathrm{H}-8), 4.11(\mathrm{t}$, $\left.J=5.9 \mathrm{~Hz}, 2 \mathrm{H}, \mathrm{H}_{2}-5\right), 3.59\left(\mathrm{~s}, 3 \mathrm{H}, \mathrm{OCH}_{3}\right), 2.68\left(\mathrm{~s}, 3 \mathrm{H}, \mathrm{CH}_{3}\right), 2.41\left(\mathrm{t}, J=7.0 \mathrm{~Hz}, 2 \mathrm{H}, \mathrm{H}_{2}-2\right)$, 1.85-1.56 (m, 4H, $\mathrm{H}_{2}-3$ and $\left.\mathrm{H}_{2}-4\right) ;{ }^{13} \mathrm{C}$ NMR (75 MHz, DMSO-d $\left.d_{6}\right) \delta 173.2\left(\mathrm{CO}_{2} \mathrm{CH}_{3}\right), 165.5$ (CO), 164.6 (C-9), 164.1 (C-7), 158.5 (C-3), 152.6 (C-4a), 138.4 (C-1), 137.7 (C-10a), 117.5 $\left(\mathrm{CH}_{2}-2\right), 108.8(\mathrm{C}-10 \mathrm{~b}), 103.6(\mathrm{CH}-10), 101.6(\mathrm{CH}-4), 99.5(\mathrm{CH}-8), 98.3(\mathrm{C}-6 \mathrm{a}), 67.8\left(\mathrm{CH}_{2}-5\right)$, $51.2\left(\mathrm{CO}_{2} \mathrm{CH}_{3}\right), 32.8\left(\mathrm{CH}_{2}-2\right), 27.8\left(\mathrm{CH}_{2}-4\right), 25.0\left(\mathrm{CH}_{3}\right), 21.1(\mathrm{C}-3)$; HRMS (TOF, ES+) $\mathrm{m} / \mathrm{z}$ calculated for $\mathrm{C}_{20} \mathrm{H}_{21} \mathrm{O}_{7}[\mathrm{M}+\mathrm{H}]^{+}$373.1282; found 373.1278.

4.2.5. Preparation of 5-((3,7-dihydroxy-1-methyl-6-oxo-6H-benzo[c]chromen-9-yl)oxy) pentanoic acid (Hapten AL $a$ )

Lipase from Candida antarctica immobilized on acrylic resin $(23 \mathrm{mg})$ was added to a solution of methyl ester $8(16.6 \mathrm{mg}, 0.0446 \mathrm{mmol})$ in a 4:1 mixture of $100 \mathrm{mM}$ sodium phosphate buffer ( $\mathrm{pH} 7.4)$ and THF $(1.5 \mathrm{~mL})$ at $30^{\circ} \mathrm{C}$. The resulting heterogeneous mixture was smoothly stirred for $24 \mathrm{~h}$ at $\mathrm{rt}$ and then filtered to separate the enzyme. The filtrated and washing THF phases were combined, diluted with EtOAc, washed with brine, dried over anhydrous $\mathrm{MgSO}_{4}$, and concentrated in vacuo to afford hapten ALa $(14.9 \mathrm{mg}, 93 \%)$ as a white amorphous solid. ${ }^{1} \mathrm{H}$ NMR $\left(300 \mathrm{MHz}, \mathrm{THF}-d_{8}\right) \delta 11.99$ and 9.19 (each s, $1 \mathrm{H}$ each, $2 \times \mathrm{OH}), 7.27(\mathrm{~d}, J=2.2 \mathrm{~Hz}, 1 \mathrm{H}, \mathrm{H}-10), 6.67(\mathrm{~d}, J=2.7 \mathrm{~Hz}, 1 \mathrm{H}, \mathrm{H}-2), 6.61(\mathrm{~d}, J=2.6 \mathrm{~Hz}, 1 \mathrm{H}$, $\mathrm{H}-4), 6.56(\mathrm{~d}, J=2.2 \mathrm{~Hz}, 1 \mathrm{H}, \mathrm{H}-8), 4.13\left(\mathrm{t}, J=6.1 \mathrm{~Hz}, 2 \mathrm{H}, \mathrm{H}_{2}-5\right), 2.78\left(\mathrm{~s}, 3 \mathrm{H}, \mathrm{CH}_{3}\right), 2.33(\mathrm{t}$, $\left.J=7.1 \mathrm{~Hz}, 2 \mathrm{H}, \mathrm{H}_{2}-2\right), 1.91-1.77\left(\mathrm{~m}, 4 \mathrm{H}, \mathrm{H}_{2}-3\right.$ and $\left.\mathrm{H}_{2}-4\right) ;{ }^{13} \mathrm{C}$ NMR $\left(126 \mathrm{MHz}\right.$, THF- $\left.d_{8}\right) \delta$ $174.5\left(\mathrm{CO}_{2} \mathrm{H}\right), 167.1$ (CO), 166.4 (C-9), 166.2 (C-7), 159.9 (C-3), 154.5 (C-4a), 139.5 (C-1), 139.2 
(C-10a), 118.5 (CH-2), 110.7 (C-10b), 105.1 (CH-10), 102.8 (CH-4), 100.3 (CH-8), 100.0 (C-6a), $69.2\left(\mathrm{CH}_{2}-5\right), 34.0\left(\mathrm{CH}_{2}-2\right), 29.6\left(\mathrm{CH}_{2}-4\right), 25.0\left(\mathrm{CH}_{3}\right.$, overlapped with solvent signal), 22.6 $\left(\mathrm{CH}_{2}-3\right)$; HRMS (TOF, ES+) $\mathrm{m} / \mathrm{z}$ calculated for $\mathrm{C}_{19} \mathrm{H}_{18} \mathrm{O}_{7}[\mathrm{M}+\mathrm{H}]^{+} 359.1125$; found 359.1122 .

4.2.6. Preparation of 2,5-dioxopyrrolidin-1-yl 5-((3,7-dihydroxy-1-methyl-6-oxo-6H-benzo [c]chromen-9-yl)oxy)pentanoate (AL $\boldsymbol{a}$-NHS Ester)

A solution of hapten AL $a(11.0 \mathrm{mg}, 30.7 \mu \mathrm{mol}), \mathrm{N}$-(3-dimethylaminopropyl)- $\mathrm{N}^{\prime}$ ethylcarbodiimide hydrochloride (EDC $\cdot \mathrm{HCl})(7.0 \mathrm{mg}, 36.8 \mu \mathrm{mol}, 1.2$ equiv) and $\mathrm{N}$-hydroxisuccinimide (NHS) $(5.0 \mathrm{mg}, 43.4 \mu \mathrm{mol}, 1.4$ equiv) in anhydrous DMF $(0.6 \mathrm{~mL})$ was stirred at rt under nitrogen overnight. The reaction mixture was diluted with $\mathrm{CH}_{2} \mathrm{Cl}_{2}$, washed with water, a $1.5 \%(w / v)$ aqueous solution of $\mathrm{LiCl}$ and brine, dried over anhydrous $\mathrm{MgSO}_{4}$ and concentrated under reduced pressure to give the $\mathrm{N}$-hydroxysuccinimidyl ester of hapten AL $\boldsymbol{a}, \mathbf{A L} \boldsymbol{a}$-NHS ester, (13.8 $\mathrm{mg}$, ca. $99 \%$ of crude product) as a slightly yellowish oil which was used immediately for the preparation of the corresponding protein bioconjugates. ${ }^{1} \mathrm{H}$ NMR $\left(500 \mathrm{MHz}\right.$, THF- $\left.d_{8}\right) \delta 11.99$ and 9.06 (each s, $1 \mathrm{H}$ each, $2 \times \mathrm{OH}$ ), $7.28(\mathrm{~d}, J=2.2 \mathrm{~Hz}, 1 \mathrm{H}, \mathrm{H}-10), 6.66(\mathrm{~d}, J=2.6 \mathrm{~Hz}, 1 \mathrm{H}, \mathrm{H}-2), 6.60(\mathrm{~d}, J=2.7 \mathrm{~Hz}, 1 \mathrm{H}, \mathrm{H}-4)$, $6.57(\mathrm{~d}, J=2.2 \mathrm{~Hz}, 1 \mathrm{H}, \mathrm{H}-8), 4.17\left(\mathrm{t}, J=5.8 \mathrm{~Hz}, 2 \mathrm{H}, \mathrm{H}_{2}-5\right), 2.78\left(\mathrm{~s}, 3 \mathrm{H}, \mathrm{CH}_{3}\right), 2.75(\mathrm{br} \mathrm{s}, 4 \mathrm{H}$, $\left.\mathrm{COCH}_{2} \mathrm{CH}_{2} \mathrm{CO}\right), 2.72\left(\mathrm{t}, J=7.0 \mathrm{~Hz}, 2 \mathrm{H}, \mathrm{H}_{2}-2\right), 1.95\left(\mathrm{~m}, 4 \mathrm{H}, \mathrm{H}_{2}-3\right.$ and $\left.\mathrm{H}_{2}-4\right)$.

\subsection{Synthesis of the N-hydroxysuccinimidyl Ester of Hapten $\boldsymbol{A L b}$}

4.3.1. Preparation of 3,5-bis(benzyloxy)-2', 4'-bis(methoxymethoxy)-6'-methyl-

[1,1'-biphenyl]-2-carbaldehyde (10)

An ampoule containing a mixture of freshly prepared aryl boronic acid 6 (104.5 mg, $0.408 \mathrm{mmol}, 2$ equiv), 2,4-bis(benzyloxy)-6-bromobenzaldehyde $9(80.9 \mathrm{mg}, 0.204 \mathrm{mmol})$, $\mathrm{K}_{2} \mathrm{CO}_{3}\left(63.6 \mathrm{mg}, 0.460 \mathrm{mmol}, 2.2\right.$ equiv) and $\mathrm{Pd}\left(\mathrm{PPh}_{3}\right)_{4}(26.6 \mathrm{mg}, 0.023 \mathrm{mmol}, 0.1$ equiv) in anhydrous DMF $(2 \mathrm{~mL})$ was exhaustively degassed by freeze-thaw cycles. The ampoule was closed under vacuum and heated at $95^{\circ} \mathrm{C}$ for $19 \mathrm{~h}$. After cooling, the ampoule was opened and the reaction mixture was poured onto water and extracted with EtOAc. The combined organic extracts were washed with water, a $1.5 \%(w / v)$ aqueous solution of $\mathrm{LiCl}$ and brine, dried under anhydrous $\mathrm{MgSO}_{4}$ and concentrated under vacuum. The resulting crude reaction mixture was chromatographed on silica gel to give biaryl-2-carbaldehyde $10(93.6 \mathrm{mg}, 77 \%)$ as a viscous yellowish oil. ${ }^{1} \mathrm{H}$ NMR $\left(500 \mathrm{MHz}, \mathrm{CDCl}_{3}\right) \delta 10.02(\mathrm{~s}, 1 \mathrm{H}$, $\mathrm{CHO}), 7.54-7.48(\mathrm{~m}, 2 \mathrm{H}, 2 \times \mathrm{CH} \mathrm{Ph}), 7.44-7.36(\mathrm{~m}, 6 \mathrm{H}, 6 \times \mathrm{CH} \mathrm{Ph}), 7.36-7.29(\mathrm{~m}, 2 \mathrm{H}, 2 \times \mathrm{CH}$ $\mathrm{Ph}), 6.72(\mathrm{~d}, J=2.4 \mathrm{~Hz}, 1 \mathrm{H}, \mathrm{H}-6), 6.65(\mathrm{~d}, J=2.3 \mathrm{~Hz}, 1 \mathrm{H}, \mathrm{H}-4), 6.64\left(\mathrm{~d}, J=2.3 \mathrm{~Hz}, 1 \mathrm{H}, \mathrm{H}-5^{\prime}\right)$, $6.37\left(\mathrm{~d}, J=2.3 \mathrm{~Hz}, 1 \mathrm{H}, \mathrm{H}-3^{\prime}\right), 5.21-5.16\left(\mathrm{~m}\right.$, two overlapped $\mathrm{AB}$ systems, $4 \mathrm{H}, \mathrm{OCH}_{2} \mathrm{O}$ and $\mathrm{OCH}_{2} \mathrm{Ph}$ ), 5.09 and $5.06\left(\mathrm{AB}\right.$ system, $J=11.7 \mathrm{~Hz}, 1 \mathrm{H}$ each, $\left.\mathrm{OCH}_{2} \mathrm{Ph}\right), 5.08$ and $4.97(\mathrm{AB}$ system, $J=6.7 \mathrm{~Hz}, 1 \mathrm{H}$ each, $\mathrm{OCH}_{2} \mathrm{O}$ ), 3.51 and 3.27 (each s, $3 \mathrm{H}$ each, $\left.2 \times \mathrm{OCH}_{3}\right), 1.96(\mathrm{~s}$, $\left.3 \mathrm{H}, \mathrm{CH}_{3} \mathrm{Ph}\right) ;{ }^{13} \mathrm{C}$ NMR $\left(126 \mathrm{MHz}, \mathrm{CDCl}_{3}\right) \delta 189.6$ (CHO), 163.5 (C-3), 162.1 (C-5), 157.6 $\left(\mathrm{C}-4^{\prime}\right), 155.1\left(\mathrm{C}-2^{\prime}\right), 144.8\left(\mathrm{C}-6^{\prime}\right), 138.1(\mathrm{C}-1), 136.4$ and $136.1(2 \times \mathrm{C} \mathrm{Ph}), 128.9(2 \times \mathrm{CH} \mathrm{Ph})$, $128.8(2 \times \mathrm{CH} \mathrm{Ph}), 128.4(\mathrm{CH} \mathrm{Ph}), 128.1 \mathrm{CH} \mathrm{Ph}), 127.7(2 \times \mathrm{CH} \mathrm{Ph}), 127.2(2 \times \mathrm{CH} \mathrm{Ph}), 123.1$ $\left(\mathrm{C}-1^{\prime}\right), 118.6(\mathrm{C}-2), 110.7\left(\mathrm{CH}-5^{\prime}\right), 109.6\left(\mathrm{CH}^{\prime} 3^{\prime}\right), 101.2(\mathrm{CH}-6), 100.1(\mathrm{CH}-4), 94.7$ and 94.6 $\left(2 \times \mathrm{OCH}_{2} \mathrm{O}\right), 70.7$ and $70.4\left(2 \times \mathrm{OCH}_{2} \mathrm{Ph}\right), 56.3$ and $56.1\left(2 \times \mathrm{OCH}_{3}\right), 20.6\left(\mathrm{CH}_{3} \mathrm{Ph}\right) ; \mathrm{HRMS}$ (TOF, ES+) $\mathrm{m} / z$ calculated for $\mathrm{C}_{32} \mathrm{H}_{33} \mathrm{O}_{7}[\mathrm{M}+\mathrm{H}]^{+} 529.2221$, found 529.2205 .

4.3.2. Preparation of 3,5-bis(benzyloxy)-2' $4^{\prime}$-bis(methoxymethoxy)-6'-methyl[1,1'-biphenyl]-2-carboxylic Acid (11)

$\mathrm{NaH}_{2} \mathrm{PO}_{4} \cdot \mathrm{H}_{2} \mathrm{O}$ (58.6 mg, $0.425 \mathrm{mmol}, 2.8$ equiv), 2-methylbut-2-ene (322.1 $\mu \mathrm{L}$, $3.04 \mathrm{mmol}, 20$ equiv) and $\mathrm{NaClO}_{2}(45.3 \mathrm{mg}, 0.501 \mathrm{mmol}, 3.3$ equiv) were successively added to a solution of biaryl-2-carbaldehyde $10(80.4 \mathrm{mg}, 0.152 \mathrm{mmol})$ in ${ }^{t} \mathrm{BuOH}(3.2 \mathrm{~mL})$ and milli-Q water $(0.4 \mathrm{~mL})$ at $0{ }^{\circ} \mathrm{C}$. The mixture was allowed to warm at $\mathrm{rt}$ and stirred for $5 \mathrm{~h}$, then diluted with an aqueous saturated solution of $\mathrm{NH}_{4} \mathrm{Cl}$ and extracted with EtOAc. The combined organic layers were washed with brine and dried over anhydrous $\mathrm{MgSO}_{4}$. Chromatography on silica gel of the residue left after evaporation of the solvent at reduced pressure, using 8:2 hexane-EtOAc as eluent, gave the biaryl-2-carboxylic acid 
$11(79.5 \mathrm{mg}, 96 \%)$ as a semi solid. ${ }^{1} \mathrm{H}$ NMR $\left(500 \mathrm{MHz}, \mathrm{CDCl}_{3}\right) \delta 9.32\left(\mathrm{~s}, 1 \mathrm{H}, \mathrm{CO}_{2} \mathrm{H}\right)$, 7.61-7.32 (m, 10H, 10xCH Ph), $6.68(\mathrm{~d}, J=2.4 \mathrm{~Hz}, 2 \mathrm{H}, \mathrm{H}-6$ and $\mathrm{H}-4), 6.65(\mathrm{~d}, J=2.4 \mathrm{~Hz}$, $\left.1 \mathrm{H}, \mathrm{H}-5^{\prime}\right), 6.44\left(\mathrm{~d}, J=2.3 \mathrm{~Hz}, 1 \mathrm{H}, \mathrm{H}-3^{\prime}\right), 5.21-5.14(\mathrm{~m}$, two overlapped AB systems, $4 \mathrm{H}$, $\mathrm{OCH}_{2} \mathrm{O}$ and $\mathrm{OCH}_{2} \mathrm{Ph}$ ), 5.07 and $5.04\left(\mathrm{AB}\right.$ system, $J=11.7 \mathrm{~Hz}, 1 \mathrm{H}$ each, $\left.\mathrm{OCH}_{2} \mathrm{Ph}\right), 4.99$ (br $\left.\mathrm{s}, 2 \mathrm{H}, \mathrm{OCH}_{2} \mathrm{O}\right), 3.50$ and 3.16 (each s, $3 \mathrm{H}$ each, $\left.2 \times \mathrm{OCH}_{3}\right), 2.01\left(\mathrm{~s}, 3 \mathrm{H}, \mathrm{CH}_{3} \mathrm{Ph}\right) ;{ }^{13} \mathrm{C} \mathrm{NMR}$ $\left(126 \mathrm{MHz}, \mathrm{CDCl}_{3}\right) \delta 165.7\left(\mathrm{CO}_{2} \mathrm{H}\right), 161.1(\mathrm{C}-3), 157.8(\mathrm{C}-5), 157.6\left(\mathrm{C}-4^{\prime}\right), 155.1\left(\mathrm{C}-2^{\prime}\right), 141.3$ (C-6'), 138.4 and $135.7(2 \times \mathrm{C} \mathrm{Ph}), 128.9(2 \times \mathrm{CH} \mathrm{Ph}), 128.8(2 \times \mathrm{CH} \mathrm{Ph}), 128.6(\mathrm{CH} \mathrm{Ph}), 128.4$ $(\mathrm{CH} \mathrm{Ph}), 127.7(2 \times \mathrm{CH} \mathrm{Ph}), 127.6(2 \times \mathrm{CH} \mathrm{Ph}), 125.1(\mathrm{C}-2), 115.9\left(\mathrm{C}-1^{\prime}\right), 111.6\left(\mathrm{CH}-5^{\prime}\right), 109.9$ $\left(\mathrm{CH}-3^{\prime}\right), 102.6(\mathrm{CH}-6), 100.3(\mathrm{CH}-4), 96.1$ and $94.7\left(2 \times \mathrm{OCH}_{2} \mathrm{O}\right), 71.5$ and $70.4\left(2 \times \mathrm{OCH}_{2} \mathrm{Ph}\right)$, 56.3 and $56.1\left(2 \times \mathrm{OCH}_{3}\right), 20.5\left(\mathrm{CH}_{3} \mathrm{Ph}\right) ; \mathrm{HRMS}$ (TOF, ES+) $\mathrm{m} / z$ calculated for $\mathrm{C}_{32} \mathrm{H}_{33} \mathrm{O}_{8}$ $[\mathrm{M}+\mathrm{H}]^{+}$545.2170, found 545.2156.

4.3.3. Preparation of 7,9-bis(benzyloxy)-3-hydroxy-1-methyl-6H-benzo[c]chromen-6-one (12)

A 50:1 $(v / v)$ mixture of ${ }^{\mathrm{i}} \mathrm{PrOH}$ and concentrated $\mathrm{HCl}(1.7 \mathrm{~mL})$ was added to a solution of biaryl-2-carboxylic acid $11(69.4 \mathrm{mg}, 0.127 \mathrm{mmol})$ in THF $(5.1 \mathrm{~mL})$ at rt under nitrogen. The mixture was thermostated at $55^{\circ} \mathrm{C}$ in an oil bath and stirred at this temperature for $24 \mathrm{~h}$. After this time, the mixture was cooled to rt, diluted with a concentrated aqueous solution of $\mathrm{NaHCO}_{3}$ and extracted with $\mathrm{Et}_{2} \mathrm{O}$. The organic phase was washed with brine, dried over anhydrous $\mathrm{MgSO}_{4}$ and concentrated under vacuum to give 7,9-bis(benzyloxy)alternariol 12 (54.7 $\mathrm{mg}, 98 \%$ ) as an amorphous whitish solid. The crude reaction product thus obtained was sufficiently pure, as judged by its NMR spectroscopic data, to be used in the next step without further purification. ${ }^{1} \mathrm{H}$ NMR $\left(500 \mathrm{MHz}\right.$, DMSO- $\left.d_{6}\right) \delta 7.58(\mathrm{~d}, J=7.4 \mathrm{~Hz}, 2 \mathrm{H}, 2 \times \mathrm{CH}$ $\mathrm{Ph}), 7.48(\mathrm{~d}, J=7.1 \mathrm{~Hz}, 2 \mathrm{H}, 2 \times \mathrm{CH} \mathrm{Ph}), 7.44-7.31(\mathrm{~m}, 6 \mathrm{H}, 6 \times \mathrm{CH} \mathrm{Ph}), 7.28(\mathrm{~d}, J=2.2 \mathrm{~Hz}, 1 \mathrm{H}$, $\mathrm{H}-10), 6.90(\mathrm{~d}, J=2.2 \mathrm{~Hz}, 1 \mathrm{H}, \mathrm{H}-8), 6.63(\mathrm{~d}, J=2.7 \mathrm{~Hz}, 1 \mathrm{H}, \mathrm{H}-2), 6.53(\mathrm{~d}, J=2.7 \mathrm{~Hz}, 1 \mathrm{H}, \mathrm{H}-4)$, 5.31 and 5.29 (each s, $2 \mathrm{H}$ each, $\left.2 \times \mathrm{OCH}_{2} \mathrm{Ph}\right), 2.63\left(\mathrm{~s}, 3 \mathrm{H}, \mathrm{CH}_{3} \mathrm{Ph}\right) ;{ }^{13} \mathrm{C} \mathrm{NMR}(126 \mathrm{MHz}$, DMSO- $d_{6}$ ) $\delta 163.6$ (CO), 162.4 (C-9), 158.4 (C-7), 156.5 (C-3), 153.7 (C-4a), 140.0 (C-1), 138.0 (C-10a), 136.8 and $136.3(2 \times \mathrm{CH} \mathrm{Ph}), 128.7(2 \times \mathrm{CH} \mathrm{Ph}), 128.5(2 \times \mathrm{CH} \mathrm{Ph}), 128.3(\mathrm{CH} \mathrm{Ph})$, 127.9 (2×CH Ph), 127.7 (CH Ph), $127.0(2 \times \mathrm{CH} \mathrm{Ph}), 116.7(\mathrm{CH}-2), 109.1$ (C-10b), $103.2(\mathrm{C}-6 \mathrm{a})$, 102.8 (CH-10), 100.9 (CH-4), $99.8(\mathrm{CH}-8), 70.1$ and $69.9\left(2 \times \mathrm{OCH}_{2} \mathrm{Ph}\right), 25.0\left(\mathrm{CH}_{3} \mathrm{Ph}\right) ; \mathrm{HRMS}$ (TOF, ES+) $m / z$ calculated for $\mathrm{C}_{28} \mathrm{H}_{23} \mathrm{O}_{5}[\mathrm{M}+\mathrm{H}]^{+} 439.1540$, found 439.1530 .

4.3.4. Preparation of methyl 5-((7,9-bis(benzyloxy)-1-methyl-6-oxo-6H-benzo[c]chromen3-yl)oxy)pentanoate (13)

Methyl bromovalerate ( $29.5 \mathrm{mg}$, ca. $22 \mu \mathrm{L}, 0.151 \mathrm{mmol}, 1.1$ equiv) was added via syringe to a stirred suspension of $\mathrm{Cs}_{2} \mathrm{CO}_{3}(57.8 \mathrm{mg}, 0.177 \mathrm{mmol}, 1.3$ equiv) and phenol $12(60.1 \mathrm{mg}, 0.137 \mathrm{mmol})$ in anhydrous DMF $(2 \mathrm{~mL})$ at $\mathrm{rt}$ under nitrogen and the mixture was stirred for $19 \mathrm{~h}$. The resulting pale yellowish reaction mixture was diluted with water and extracted with EtOAc. The combined organic extracts were washed successively with water, a $1.5 \%(w / v)$ aqueous solution of $\mathrm{LiCl}$ and brine, dried over anhydrous $\mathrm{MgSO}_{4}$ and concentrated under reduced pressure. The crude reaction product was purified by chromatography on silica gel, using $\mathrm{CHCl}_{3}$ as eluent, to afford the $\mathrm{O}$-alkylated product $13(71.4 \mathrm{mg}, 94 \%)$ as a pale yellowish semi-solid. ${ }^{1} \mathrm{H}$ NMR $\left(500 \mathrm{MHz}, \mathrm{CDCl}_{3}\right) \delta 7.59(\mathrm{~m}$, $2 \mathrm{H}, \mathrm{CH} \mathrm{Ph}), 7.43-7.34(\mathrm{~m}, 8 \mathrm{H}, 8 \times \mathrm{CH} \mathrm{Ph}), 7.30(\mathrm{~d}, J=2.3 \mathrm{~Hz}, 1 \mathrm{H}, \mathrm{H}-2), 6.67(\mathrm{~d}, J=2.7 \mathrm{~Hz}$, $1 \mathrm{H}, \mathrm{H}-10), 6.64(\mathrm{~d}, J=4.6 \mathrm{~Hz}, 2 \mathrm{H}, \mathrm{H}-4), 6.64(\mathrm{~s}, 1 \mathrm{H}, \mathrm{H}-8), 5.28$ and 5.16 (each s, 2H each, $\left.2 \times \mathrm{OCH}_{2} \mathrm{Ph}\right), 4.00\left(\mathrm{t}, J=5.5 \mathrm{~Hz}, 2 \mathrm{H}, \mathrm{H}_{2}-5\right), 3.68\left(\mathrm{~s}, 3 \mathrm{H}, \mathrm{CO}_{2} \mathrm{CH}_{3}\right), 2.67\left(\mathrm{~s}, 3 \mathrm{H}, \mathrm{CH}_{3}\right), 2.41(\mathrm{t}$, $\left.J=6.9 \mathrm{~Hz}, 2 \mathrm{H}, \mathrm{H}_{2}-2\right), 1.84\left(\mathrm{~m}, 4 \mathrm{H}, \mathrm{H}_{2}-3\right.$ and $\left.\mathrm{H}_{2}-4\right) ;{ }^{13} \mathrm{C} \mathrm{NMR}\left(126 \mathrm{MHz}, \mathrm{CDCl}_{3}\right) \delta 173.9$ $\left(\mathrm{CO}_{2} \mathrm{CH}_{3}\right), 163.7(\mathrm{CO}), 162.9$ (C-9), 159.5 (C-7), 157.8 (C-3), 154.3 (C-4a), 140.7 (C-1), 137.4 (C-10a), 136.5 and $135.9(2 \times \mathrm{C} \mathrm{Ph}), 129.0(2 \times \mathrm{CH} \mathrm{Ph}), 128.8(2 \times \mathrm{CH} \mathrm{Ph}), 128.6(\mathrm{CH} \mathrm{Ph}), 127.9$ (CH Ph), 127.5 ( $2 \times \mathrm{CH} \mathrm{Ph}), 126.8(2 \times \mathrm{CH} \mathrm{Ph}), 116.7$ (CH-2), 111.0 (C-10b), 104.5 (C-6a), 103.9 (CH-10), $100.0(\mathrm{CH}-4), 99.9(\mathrm{CH}-8), 71.0$ and $70.5\left(\right.$ each $\left.\mathrm{OCH}_{2} \mathrm{Ph}\right), 67.7\left(\mathrm{CH}_{2}-5\right), 51.7\left(\mathrm{OCH}_{3}\right)$, 33.8 $\left(\mathrm{CH}_{2}-2\right), 28.6\left(\mathrm{CH}_{2}-4\right), 25.6\left(\mathrm{CH}_{3}\right), 21.7\left(\mathrm{CH}_{2}-3\right)$; HRMS (TOF, ES+) $\mathrm{m} / z$ calculated for $\mathrm{C}_{34} \mathrm{H}_{33} \mathrm{O}_{7}[\mathrm{M}+\mathrm{H}]^{+}$553.2221, found 553.2112. 
4.3.5. Preparation of 5-((7,9-bis(benzyloxy)-1-methyl-6-oxo-6H-benzo[c]chromen-3-yl)oxy) pentanoic Acid (14)

The hydrolysis of the methyl ester moiety of $\mathbf{1 3}$ was performed following the same procedure reported for the hydrolysis of ester $\mathbf{8}$ to obtain hapten AL $a$. The methyl ester $\mathbf{1 3}$ $(17.5 \mathrm{mg}, 0.032 \mathrm{mmol})$, lipase from Candida antarctica immobilized on acrylic resin $(16 \mathrm{mg})$ and a 4:1 mixture of $100 \mathrm{mM}$ sodium phosphate buffer (pH 7.4) and THF (1.1 mL). Workup as described for the hydrolysis of 8 yielded acid $\mathbf{1 4}(17.0 \mathrm{mg}, 99 \%)$ as a whitish semi-solid. ${ }^{1} \mathrm{H}$ NMR (500 MHz, THF- $\left.d_{8}\right) \delta 7.68(\mathrm{~m}, 2 \mathrm{H}, 2 \times \mathrm{CH} \mathrm{Ph}), 7.46(\mathrm{~m}, 2 \mathrm{H}, 2 \times \mathrm{CH} \mathrm{Ph}), 7.40-7.30$ $(\mathrm{m}, 6 \mathrm{H}, 4 \times \mathrm{CH} \mathrm{Ph}$ and $\mathrm{H}-2), 7.25(\mathrm{br} \mathrm{t}, J=7.5 \mathrm{~Hz}, 1 \mathrm{H}, \mathrm{CH} \mathrm{Ph}), 6.85(\mathrm{~d}, J=2.2 \mathrm{~Hz}, 1 \mathrm{H}, \mathrm{H}-10)$, $6.71(\mathrm{~d}, J=2.8 \mathrm{~Hz}, 1 \mathrm{H}, \mathrm{H}-4), 6.69(\mathrm{~d}, J=2.8 \mathrm{~Hz}, 1 \mathrm{H}, \mathrm{H}-8), 5.26\left(\mathrm{~s}, 4 \mathrm{H}, 2 \times \mathrm{OCH}_{2} \mathrm{Ph}\right), 4.05$ $\left(\mathrm{t}, J=6.2 \mathrm{~Hz}, 2 \mathrm{H}, \mathrm{H}_{2}-5\right), 2.71\left(\mathrm{~s}, 3 \mathrm{H}, \mathrm{Ar}_{-} \mathrm{CH}_{3}\right), 2.32\left(\mathrm{t}, J=7.2 \mathrm{~Hz}, 2 \mathrm{H}, \mathrm{H}_{2}-2\right), 1.78(\mathrm{~m}, 4 \mathrm{H}$, $\mathrm{H}_{2}-3$ and $\left.\mathrm{H}_{2}-4\right) .{ }^{13} \mathrm{C}$ NMR $\left(126 \mathrm{MHz}\right.$, THF- $\left.d_{8}\right) \delta 174.5\left(\mathrm{CO}_{2} \mathrm{H}\right), 164.8(\mathrm{CO}), 163.9(\mathrm{C}-9), 160.9$ (C-7), 156.7 (C-3), 155.7 (C-4a), 141.4 (C-1), 138.5 (C-10a), 138.3 and 137.9 (each C Ph), 129.5 $(2 \times \mathrm{CH} \mathrm{Ph}), 129.2(2 \times \mathrm{CH} \mathrm{Ph}), 129.0(\mathrm{CH} \mathrm{Ph}), 128.5(2 \times \mathrm{CH} \mathrm{Ph}), 128.2(\mathrm{CH} \mathrm{Ph}), 127.6(2 \times \mathrm{CH}$ $\mathrm{Ph}), 117.2$ (CH-2), 111.8 (C-10b), 105.4 (C-6a), 104.5 (CH-10), 100.7 (CH-4), 100.5 (CH-8), 71.4 and 71.1 (each $\left.\mathrm{OCH}_{2} \mathrm{Ph}\right), 68.8\left(\mathrm{CH}_{2}-5\right), 34.0\left(\mathrm{CH}_{2}-2\right), 29.7\left(\mathrm{CH}_{2}-4\right), 26.5\left(\mathrm{CH}_{3}\right), 22.6$ $\left(\mathrm{CH}_{2}-3\right.$ ); HRMS (TOF, ES+) $\mathrm{m} / \mathrm{z}$ calculated for $\mathrm{C}_{33} \mathrm{H}_{31} \mathrm{O}_{7}[\mathrm{M}+\mathrm{H}]^{+} 539.2064$, found 539.2073 .

4.3.6. Preparation of 2,5-dioxopyrrolidin-1-yl 5-((7,9-dihydroxy-1-methyl-6-oxo-6H-benzo [c]chromen-3-yl)oxy)pentanoate (AL $b$-NHS Ester)

The acid 14 obtained in the above step $(15.1 \mathrm{mg}, 28 \mu \mathrm{mol})$ was transformed into the corresponding $N$-hydroxysuccinimidyl ester $15(17.2 \mathrm{mg})$ following the same procedure previously described for the transformation of hapten AL $a$ into AL $a$-NHS ester, using $\mathrm{EDC} \cdot \mathrm{HCl}(6.4 \mathrm{mg}, 33.6 \mu \mathrm{mol}, 1.2$ equiv) and NHS ( $4.2 \mathrm{mg}, 36.5 \mu \mathrm{mol}, 1.3$ equiv) in anhydrous DMF (1 mL). ${ }^{1} \mathrm{H}$ NMR ( $\left.300 \mathrm{MHz}, \mathrm{CDCl}_{3}\right) \delta 7.59(\mathrm{~m}, 2 \mathrm{H}, 2 \times \mathrm{CH} \mathrm{Ph}), 7.45-7.32(\mathrm{~m}, 8 \mathrm{H}$, $8 \times \mathrm{CH} \mathrm{Ph}), 7.31(\mathrm{~d}, J=2.3 \mathrm{~Hz}, 1 \mathrm{H}, \mathrm{H}-2), 6.69(\mathrm{~d}, J=2.7 \mathrm{~Hz}, 1 \mathrm{H}, \mathrm{H}-10), 6.67(\mathrm{~d}, J=2.7 \mathrm{~Hz}$, $1 \mathrm{H}, \mathrm{H}-4), 6.65(\mathrm{~d}, J=2.2 \mathrm{~Hz}, 1 \mathrm{H}, \mathrm{H}-8), 5.29$ and 5.17 (each s, $2 \mathrm{H}$ each, $\left.2 \times \mathrm{OCH}_{2} \mathrm{Ph}\right), 4.04(\mathrm{t}$, $\left.J=5.6 \mathrm{~Hz}, 2 \mathrm{H}, \mathrm{H}_{2}-5\right), 2.85\left(\mathrm{br} \mathrm{s}, 4 \mathrm{H}, \mathrm{COCH}_{2} \mathrm{CH}_{2} \mathrm{CO}\right), 2.72\left(\mathrm{t}, J=6.9 \mathrm{~Hz}, 1 \mathrm{H}, \mathrm{H}_{2}-2\right), 2.68(\mathrm{~s}$, $\left.3 \mathrm{H}, \mathrm{CH}_{3}\right), 1.96\left(\mathrm{~m}, 4 \mathrm{H}, \mathrm{H}_{2}-3\right.$ and $\left.\mathrm{H}_{2}-4\right)$.

Thereafter, a suspension of $5 \% \mathrm{Pd} / \mathrm{C}(8 \mathrm{mg})$ and 15 in acetone $(3 \mathrm{~mL})$ was degassed and purged with hydrogen by several cycles of freeze-pump-thaw using a water aspirator pump. The hydrogen pressure was adjusted to $1.5 \mathrm{~atm}$ and the mixture was stirred vigorously overnight at rt. The reaction mixture was filtered through a disposable Teflon membrane filter $(0.45 \mu \mathrm{m})$, and the filtrate and washing THF phases were combined and concentrated at reduced pressure to give the $N$-hydroxysuccinimidyl ester of hapten AL $b$, AL $b$-NHS ester, (12.2 mg, 95\% of crude product from 14) as a viscous colorless oil which was used immediately for the preparation of the corresponding protein bioconjugates. ${ }^{1} \mathrm{H}$ NMR (500 MHz, THF- $d_{8} /$ DMSO-d $_{6}$ ) $\delta 11.92$ and 9.67 (each s, $1 \mathrm{H}$ each, $2 \times \mathrm{OH}$ ), 7.24 (d, $J=2.1 \mathrm{~Hz}, 1 \mathrm{H}, \mathrm{H}-2), 6.83(\mathrm{~d}, J=2.7 \mathrm{~Hz}, 1 \mathrm{H}, \mathrm{H}-4), 6.82(\mathrm{~d}, J=2.6 \mathrm{~Hz}, 1 \mathrm{H}, \mathrm{H}-10), 6.36$ $(\mathrm{d}, J=2.1 \mathrm{~Hz}, 1 \mathrm{H}, \mathrm{H}-8), 4.10\left(\mathrm{t}, J=5.6 \mathrm{~Hz}, 1 \mathrm{H}, \mathrm{H}_{2}-5\right), 2.79\left(\mathrm{~s}, 3 \mathrm{H}, \mathrm{CH}_{3}\right), 2.76(\mathrm{br} \mathrm{s}, 4 \mathrm{H}$, $\left.\mathrm{COCH}_{2} \mathrm{CH}_{2} \mathrm{CO}\right), 2.71\left(\mathrm{t}, J=6.9 \mathrm{~Hz}, 2 \mathrm{H}, \mathrm{H}_{2}-2\right), 1.93\left(\mathrm{~m}, 4 \mathrm{H}, \mathrm{H}_{2}-3\right.$ and $\left.\mathrm{H}_{2}-4\right)$.

\subsection{Immunoreagent Preparation}

Protein conjugates of the two haptens were obtained by the active ester method. A $50 \mathrm{mM}$ solution of the activated hapten was prepared in DMSO. BSA and OVA solutions were prepared at $15 \mathrm{mg} / \mathrm{mL}$ in $50 \mathrm{mM}$ carbonate buffer, $\mathrm{pH}$ 9.6. The activated hapten was added to the protein solution at 40-fold molar excess for BSA conjugates. Conjugation reactions to OVA were done with 8- or 11-fold excess for AL $a$ and $\mathbf{A L} b$, respectively. Concerning HRP conjugates, the activated hapten solution $(5 \mathrm{mM})$ was added over a $3 \mathrm{mg} / \mathrm{mL}$ enzyme solution in the same carbonate buffer to reach a hapten molar excess of 15. The activated haptens were added slowly to the protein solution (ca. 15-20 $\mu \mathrm{L}$ per hour), and the mixtures were incubated overnight at rt, protected from light, and with gentle stirring. Then, they were centrifuged for $5 \mathrm{~min}$ at $6700 \times g$, and the conjugates were purified from the supernatant by size-exclusion chromatography using $100 \mathrm{mM}$ phosphate 
buffer, $\mathrm{pH}$ 7.4, as eluent. Fractions containing BSA or OVA conjugates were pooled and diluted with elution buffer to a final concentration of $1 \mathrm{mg} / \mathrm{mL}$. BSA conjugate solutions were passed through $0.45 \mu \mathrm{m}$ sterile filters. BSA and OVA conjugate solutions were stored at $-20{ }^{\circ} \mathrm{C}$. HRP conjugate solutions were $1: 1$ diluted with PBS containing $1 \%$ BSA $(w / v)$ and $0.02 \%(w / v)$ thimerosal and stored at $4{ }^{\circ} \mathrm{C}$. The hapten-to-protein molar ratio of the prepared conjugates was determined by MALDI-TOF-MS and running BSA, OVA, and HRP for reference in the same plate, as previously described [27].

Animal manipulation was performed according to Spanish laws (RD1201/2005 and law 32/2007) and the European Directive 2010/63EU regarding the protection of experimental animals. Polyclonal antibodies to $\mathrm{AOH}$ and AME were obtained from the sera of immunized animals. Briefly, two female New Zealand white rabbits-weighing $2 \mathrm{~kg}$ at the beginning of the experiment-were immunized by four periodic subcutaneous injections of a 1:1 water-in-oil emulsion containing $300 \mu \mathrm{g}$ of the BSA-hapten conjugate. The inoculum was prepared with complete Freund's adjuvant for the first injection and with incomplete Freund's adjuvant for subsequent injections. Boosts were applied with 21-day intervals. Animals were exsanguinated by intracardiac puncture 10 days after the last injection, and the blood was left overnight in the refrigerator at $4{ }^{\circ} \mathrm{C}$ for coagulation. Sera were separated from cells by centrifugation $(3000 \times g, 20 \mathrm{~min})$. Finally, immunoglobulins were partially purified by precipitation twice with one volume of cold saturated (3.9 M) ammonium sulphate solution. Antibodies were stored at $4{ }^{\circ} \mathrm{C}$ as precipitates.

\subsection{Competitive ELISA Procedures}

Immunoassays were carried out by competitive ELISA using the capture antibodycoated direct format and the conjugate-coated indirect format. After each incubation step, plates were washed three times with a $150 \mathrm{mM} \mathrm{NaCl}$ solution containing $0.05 \%(v / v)$ Tween 20. For direct assays, microplates were coated by overnight incubation at $4{ }^{\circ} \mathrm{C}$ with $100 \mu \mathrm{L}$ per well of GAR solution $(1 \mu \mathrm{g} / \mathrm{mL})$ in $50 \mathrm{mM}$ carbonate-bicarbonate buffer, $\mathrm{pH}$ 9.6. For indirect assays, microwells were coated with $100 \mu \mathrm{L}$ per well of OVA-hapten conjugate solution in the same coating buffer, and overnight incubation at rt. The competitive reaction was performed by mixing in each well $50 \mu \mathrm{L}$ of analyte solution in PBS with $50 \mu \mathrm{L}$ of antibody dilution or enzyme tracer solution in PBS containing $0.05 \%(v / v)$ of Tween-20, and incubating $1 \mathrm{~h}$ at rt. For indirect assays, $100 \mu \mathrm{L}$ per well of GAR-HRP diluted 1/10,000 in PBS containing $0.05 \%(v / v)$ of Tween- 20 and $10 \%(v / v)$ of adult bovine serum was added. Signal was obtained using $100 \mu \mathrm{L}$ per well of TMB as the chromogenic enzyme substrate and incubation at rt during $10 \mathrm{~min}$. Finally, $100 \mu \mathrm{L}$ of $1 \mathrm{M} \mathrm{H}_{2} \mathrm{SO}_{4}$ was added and the absorbance was read at $450 \mathrm{~nm}$ using $650 \mathrm{~nm}$ as reference wavelength.

Standard mycotoxin solutions were obtained by serially diluting in buffer the most concentrated standard solution, which was prepared from a concentrated stock solution in DMF. Eight-point standard curves were built using those solutions and a blank sample. SigmaPlot software, version 14.0 from Systat Software Inc. (San Jose, CA, USA), was employed to fit the experimental values to a standard four-parameter logistic equation. The half-maximal inhibition concentration $\left(\mathrm{IC}_{50}\right)$ and the maximum absorbance $\left(\mathrm{A}_{\max }\right)$ values were considered in order to compare antibody performance. CR was calculated according to Formula (1):

$$
\mathrm{CR}(\%)=\mathrm{IC}_{50}(\mathrm{AOH}) / \mathrm{IC}_{50}(\mathrm{AME}) \times 100
$$

Supplementary Materials: The following are available online at https:/ / www.mdpi.com/article / 10.3390/toxins13120883/s1: General procedures, materials, and equipment; NMR spectra of all of the intermediates and the final activated haptens.

Author Contributions: Conceptualization, A.A.-F.; Data curation, A.A.-S., A.A.-F. and J.V.M.; Formal analysis, L.G.A.-M., A.A.-S. and C.A.; Funding acquisition, A.A.-S., A.A.-F. and J.V.M.; Investigation, L.G.A.-M. and C.A.; Methodology, A.A.-S., A.A.-F. and J.V.M.; Supervision, A.A.-S., C.A. and J.V.M.; Validation, L.G.A.-M. and C.A.; Writing-original draft, A.A.-S. and J.V.M.; Writing-review \& 
editing, A.A.-S., A.A.-F. and J.V.M. All authors have read and agreed to the published version of the manuscript.

Funding: This research was funded by the SPANISH MINISTERIO DE ECONOMÍA Y COMPETITIVIDAD, grant numbers AGL2015-64488 and RTI2018-096121, and cofinanced by EUROPEAN REGIONAL DEVELOPMENT FUNDS. Animal manipulation as well as mass, spectrometric, and proteomic analysis was performed at the SCSIE service of the University of Valencia. The proteomics laboratory is a member of Proteored.

Institutional Review Board Statement: This study was conducted according to the guidelines of the Declaration of Helsinki, and approved by the Institutional Review Board of GENERALITAT VALENCIANA (protocol code 2019/VSC/PEA/0179) on 20 August 2019.

Informed Consent Statement: Not applicable.

Data Availability Statement: Not applicable.

Acknowledgments: The technical assistance by Paula Peña-Murgui and José V. Gimeno is greatly appreciated.

Conflicts of Interest: The authors declare no conflict of interest.

\section{References}

1. Escrivá, L.; Oueslati, S.; Font, G.; Manyes, L. Alternaria mycotoxins in food and feed: An overview. J. Food Qual. 2017, 2017, 1569748. [CrossRef]

2. EFSA Panel on Contaminants in the Food Chain (CONTAM). Scientific Opinion on the risks for animal and public health related to the presence of Alternaria toxins in feed and food. EFSA J. 2011, 9, 2407. [CrossRef]

3. Arcella, D.; Eskola, M.; Gómez-Ruiz, J.A. EFSA Scientific Report. Dietary exposure assessment to Alternaria toxins in the European population. EFSA J. 2016, 14, 4654. [CrossRef]

4. Ostry, V. Alternaria mycotoxins: An overview of chemical characterization, producers, toxicity, analysis and occurrence in foodstuffs. World Mycotoxin J. 2008, 1, 175-188. [CrossRef]

5. Saha, D.; Fetzner, R.; Burkhardt, B.; Podlech, J.; Metzler, M.; Dang, H.; Lawrence, C.; Fischer, R. Identification of a polyketide synthase required for alternariol (AOH) and alternariol-9-methyl ether (AME) formation in Alternaria alternata. PLoS ONE 2012, 7, e40564. [CrossRef] [PubMed]

6. Solfrizzo, M. Recent advances on Alternaria mycotoxins. Curr. Opin. Food Sci. 2017, 17, 57-61. [CrossRef]

7. Hickert, S.; Bergmann, M.; Ersen, S.; Cramer, B.; Humpf, H.-U. Survey of Alternaria toxin contamination in food from the German market, using a rapid HPLC-MS/MS approach. Mycotoxin Res. 2016, 32, 7-18. [CrossRef] [PubMed]

8. Man, Y.; Liang, G.; Li, A.; Pan, L. Analytical methods for the determination of Alternaria mycotoxins. Chromatographia 2017, 80, 9-22. [CrossRef]

9. Chen, A.; Mao, X.; Sun, Q.; Wei, Z.; Li, J.; You, Y.; Zhao, J.; Jiang, G.; Wu, Y.; Wang, L.; et al. Alternaria mycotoxins: An overview of toxicity, metabolism, and analysis in food. J. Agric. Food Chem. 2021, 69, 7817-7830. [CrossRef]

10. Burkin, A.A.; Kononenko, G.P. Enzyme immunassay of alternariol for the assessment of risk of agricultural products contamination. Appl. Biochem. Microbiol. 2011, 47, 72-76. [CrossRef]

11. Ackermann, Y.; Curtui, V.; Dietrich, R.; Gross, M.; Latif, H.; Märtlbauer, E.; Usleber, E. Widespread occurrence of low levels of alternariol in apple and tomato products, as determined by comparative immunochemical assessment using monoclonal and polyclonal antibodies. J. Agric. Food Chem. 2011, 59, 6360-6368. [CrossRef]

12. Kong, D.; Xie, Z.; Liu, L.; Song, S.; Zheng, Q.; Kuang, H. Development of an immunochromatographic assay for the detection of alternariol in cereal and fruit juice samples. Food Agric. Immunol. 2017, 28, 1082-1093. [CrossRef]

13. Singh, G.; Velasquez, L.; Brady, B.; Koerner, T.; Huet, A.-C.; Delahaut, P. Development of an indirect competitive ELISA for analysis of alternariol in bread and bran samples. Food Anal. Methods 2018, 11, 1444-1450. [CrossRef]

14. Man, Y.; Liang, G.; Jia, F.; Li, A.; Fu, H.; Wang, M.; Pan, L. Development of an immunochromatographic strip test for the rapid detection of alternariol monomethyl ether in fruit. Toxins 2017, 9, 152. [CrossRef] [PubMed]

15. Wang, J.; Peng, T.; Zhang, X.; Yao, K.; Ke, Y.; Shao, B.; Wang, Z.; Shen, J.; Jiang, H. A novel hapten and monoclonal antibody-based indirect competitive ELISA for simultaneous analysis of alternariol and alternariol monomethyl ether in wheat. Food Control 2018, 94, 65-70. [CrossRef]

16. Yao, C.-Y.; Xu, Z.-L.; Wang, H.; Zhu, F.; Luo, L.; Yang, J.-Y.; Sun, Y.-M.; Lei, H.-T.; Tian, Y.-X.; Shen, Y.-D. High affinity antibody based on a rationally designed hapten and development of a chemiluminescence enzyme immunoassay for quantification of alternariol in fruit juice, maize and flour. Food Chem. 2019, 283, 359-366. [CrossRef]

17. Bräse, S.; Gläser, F.; Kramer, C.; Lindner, S.; Linsenmeier, A.M.; Masters, K.-S.; Meister, A.C.; Ruff, B.M.; Zhong, S. The Chemistry of Mycotoxins; Springer: Berlin/Heidelberg, Germany, 2013; Chapter 11; Volume 97, pp. 127-137.

18. Koch, K.; Podlech, J.; Pfeiffer, E.; Metzler, M. Total synthesis of alternariol. J. Org. Chem. 2005, 70, 3275-3276. [CrossRef] 
19. Liang, D.; Luo, H.; Liu, Y.-F.; Hao, Z.-Y.; Wang, Y.; Zhang, C.-L.; Zhang, Q.J.; Chen, R.-Y.; Yu, D.-Q. Lysilactones A-C, three 6H-dibenzo[b,d]pyran-6-one glycosides from Lysimachia clethroides, total synthesis of lysilactone A. Tetrahedron 2013, 69, $2093-2097$. [CrossRef]

20. Won, M.; Kwon, S.; Kim, T.-H. An efficient synthesis of alternariol. J. Korean Chem. Soc. 2015, 59, 471-474. [CrossRef]

21. Martinez-Solorio, D.; Belmore, K.A.; Jennings, M.P. Synthesis of the purported ent-pochonin J structure featuring a stereoselective oxocarbenium allylation. J. Org. Chem. 2011, 76, 3898-3908. [CrossRef]

22. Mallampudi, N.A.; Choudhury, U.M.; Mohapatra, D.K. Total synthesis of (-)-citreoisocoumarin, (-)-citreoisocoumarinol, (-)-12epi-citreoisocoumarinol, and (-)-mucorisocoumarins A and B using a gold(I)-catalyzed cyclization strategy. J. Org. Chem. 2020, 85, 4122-4129. [CrossRef] [PubMed]

23. Hinman, A.W.; Davis, D.; Kheifets, V. Preparation of Resorcinol Compounds for Dermatological Use. U.S. Patent 20140256830 A1, 6 March 2014.

24. Marcyk, P.; Brown, L.E.; Huang, D.; Cowen, L.E.; Whitesell, L. Preparation of Resorcylate Aminopyrazole Compounds as Hsp90 Inhibitors and Uses. Thereof. Patent WO 2020/227368 A1, 6 May 2020.

25. Roedel, T.; Gerlach, H. Enantioselective synthesis of the polyketide antibiotic (3R,4S)-(-)-citrinin. Liebigs Ann. 1995, 5, 885-888. [CrossRef]

26. Lozada, J.; Liu, Z.; Perrin, D.M. Base-promoted protodeboronation of 2,6-disubstituted arylboronic acids. J. Org. Chem. 2014, 79, 5365-5368. [CrossRef] [PubMed]

27. López-Puertollano, D.; Mercader, J.V.; Agulló, C.; Abad-Somovilla, A.; Abad-Fuentes, A. Novel haptens and monoclonal antibodies with subnanomolar affinity for a classical analytical target, ochratoxin A. Sci. Rep. 2018, 8, 9761. [CrossRef] [PubMed] 